\title{
MIGRACIJSKA KOMPONENTA UKUPNOGA KRETANJA STANOVNIŠTVA VUKOVARSKO-SRIJEMSKE ŽUPANIJE 2001. - 2017.
}

Predmet demografske analize u ovomu radu su sastavnice/odrednice ukupnoga kretanja stanovništva i demografske bilance Vukovarsko-srijemske županije u razdoblju od popisa 2001. do 2017. godine, s posebnim naglaskom na mehaničku (migracijsku) komponentu ukupnoga kretanja stanovništva. Istraživanjem se želi utvrditi veličina i struktura demografske bilance, komparativnom vitalnostatističkom metodom procijeniti gruba migracijska bilanca te za tematizirano razdoblje ocijeniti važnost suvremenih migracija za kretanje i razvoj stanovništva Vukovarsko-srijemske županije (ukupno te na razini jedinica lokalne samouprave - gradova i općina) radi prepoznavanja dominantnih suvremenih dinamičkih obilježja njezina demografskog razvoja. Demografska analiza provedena je na temelju demografsko-statističke dokumentacije iz dostupne (objavljene) popisne, vitalne i migracijske statistike. Komparativnom analizom utvrđeno je da Vukovarsko-srijemska županija ima ukupnu depopulaciju kao tip međupopisne promjene, prirodno smanjenje kao posljedicu brojnijega umiranja pri rađanju te negativan saldo ukupne migracije kao rezultat brojnijega iseljavanja od doseljavanja stanovništva. Demografska je bilanca Vukovarsko-srijemske županije stoga negativna i u razdoblju nakon posljednjega popisa stanovništva 2011. godine. Prevladavajuća odrednica negativne migracijske bilance jest jaka emigracija, kako u druge hrvatske županije, tako i sve više u inozemstvo. Brojčano sve veći gubitak stanovništva prirodnim i osobito mehaničkim putem (iseljavanjem) izrazito je nepovoljna dugoročna odrednica demografske, društvene i ekonomske revitalizacije $\mathrm{Vu}$ kovarsko-srijemske županije, teško stradale u ratnoj agresiji 1990-ih godina.

Ključne riječi: Vukovarsko-srijemska županija; ukupno kretanje; prirodno kretanje; migracije; demografska bilanca; depopulacija; demografsko starenje.

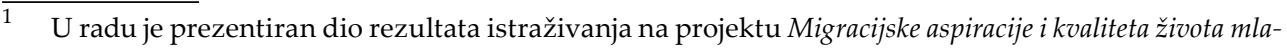
dih u Vukovarsko-srijemskoj županiji (MAVUS) (2018. - 2019.), financiranom sredstvima Ministarstva znanosti i obrazovanja (MZO) u okviru programa višegodišnjega institutskoga financiranja (VIF). 


\section{UVOD}

Već niz godina hrvatski demografi u svojim znanstvenim radovima, ali i javnim istupima dokumentirano upozoravaju na višestruko složene uzroke i alarmantne posljedice „hrvatskoga demografskoga sloma“" te predvidljiv dramatičan epilog višegodišnjega zanemarivanja demografske problematike od strane hrvatskih upravljačkih elita. ${ }^{3}$ Hrvatska se već gotovo tri desetljeća nalazi u općoj depopulaciji, koja je rezultat parcijalnih depopulacijskih procesa započetih još krajem 1950-ih godina. S punim će pravom A. Wertheimer-Baletić upozoriti da „proces ukupne depopulacije u demografskim uvjetima ubrzanog starenja dobne strukture stanovništva, procesa koji u Hrvatskoj traje već od početka 1970-ih godina, znači izumiranje, nestajanje stanovništva. Taj je demografski proces temeljna značajka sadašnje demografske situacije u Hrvatskoj koja, ceteris paribus, dugoročno determinira buduće demografske trendove, kako agregatne tako i

$\overline{2}$ Usp. izbor iz novije demografske literature (abecednim redom): Akrap, Anđelko, 2014. Promjene broja i prostornog razmještaja stanovništva Hrvatske i županija 1961. - 2011., u: Migracije i razvoj Hrvatske. Podloga za hrvatsku migracijsku strategiju (Puljiz, Vlado, Tica, Josip, Vidović, Davorko, ur.), Zagreb: Hrvatska gospodarska komora, 25-71; Aračić, Pero (gl. ur.), 2018. Kamo ide istočna Hrvatska? Demografsko stanje, prognoze i traženje izlaska iz krize Slavonije, Baranje i zapadnog Srijema, Zbornik radova sa znanstvenoga skupa, Zagreb - Đakovo: Hrvatska akademija znanosti i umjetnosti. Zavod za znanstveni i umjetnički rad u Đakovu; Gelo, Jakov, Akrap, Anđelko, Čipin, Ivan, 2005. Temeljne značajke demografskog razvoja Hrvatske (bilanca 20. stoljeća), Zagreb: Ministarstvo obitelji, branitelja i međugeneracijske solidarnosti; Nejašmić, Ivo, 2008. Stanovništvo Hrvatske: demogeografske studije $i$ analize, Zagreb: Hrvatsko geografsko društvo; Nejašmić, Ivo, 2014. Iseljavanje iz Hrvatske od 1900. do 2001.: demografske posljedice stoljetnog procesa, Migracijske i etničke teme, 30, 3, 405-435; Pokos, Nenad, 2017. Osnovna demografska obilježja suvremenog iseljavanja iz Hrvatske, Političke analize, 31, 16-23; Wertheimer-Baletić, Alica, 2017.a. Demografska teorija, razvoj stanovništva Hrvatske i populacijska politika (Izbor radova), Samobor: Meridijani izdavačka kuća.

3 Razmatrajući ulogu i posljedice suvremenoga iseljavanja iz Hrvatske kao i trenutnih te predvidivih trendova u bioreprodukciji hrvatskoga stanovništva, A. Akrap, M. Strmota i K. Ivanda opravdano zaključuju da će „,svakom daljnjom godinom Hrvatska [će] imati sve lošiju demografsku, ekonomsko-socijalnu i obrazovnu strukturu stanovništva te bez zadrške i preuveličavanja demografske problematike sa sigurnošću možemo tvrditi kako su pred našom zemljom veliki izazovi. Više desetljetno zanemarivanje i ignoriranje demografskih pokazatelja i trendova dovelo nas je do pred demografski i ekonomski slom" (Akrap, Anđelko, Strmota, Marin, Ivanda, Krešimir, 2017. Iseljavanje iz Hrvatske od početka 21. stoljeća: uzroci i posljedice, u: Zbornik radova Hrvatska izvan Domovine II (Sopta, Marin, Lemić, Vlatka, Korade, Mijo, Rogić, Ivan, Perić Kaselj, Marina, ur.), Zagreb: Centar za istraživanje hrvatskog iseljeništva, str. 550). Promišljajući i analizirajući fenomen hrvatskih migracija početkom 21. stoljeća, i prije brojnoga iseljeničkoga vala posljednjih nekoliko godina koji još uvijek ne jenjava, I. Lajić je konstatirao da „, i u novoj migracijskoj konstelaciji migracije djeluju nepovoljno na demografski razvoj Hrvatske. Unutarnja demografska polarizacija Hrvatske (propulzivni prostori na jednoj, nasuprot sve širem depopulacijskom polu na drugoj strani) se pojačava, jer se vitalnost demografskih zbivanja (prirodni prirast i pozitivan migracijski saldo) veže uz najveće gradove, što stvara dodatni problem asimetričnog prostornog razvoja snaženjem oligocentričnog značenja glavnih gradova hrvatskih regija" (Lajić, Ivan, 2002. Hrvatske migracije početkom 21. stoljeća, Migracijske i etničke teme, 18, 2-3, str. 136). 
strukturne“. ${ }^{4}$ Sadržajna i prostorna (geografska) rasprostranjenost ukupne depopulacije potvrđuje dubinu i kauzalnu složenost demografske krize u kojoj se Hrvatska nalazi; ujedno upućuje na sporost, pa i potpunu odsutnost strateškoga promišljanja kako i na koji način usporiti i ublažiti sve izvjesniji „demografski sunovrat". Recentni podatci hrvatske vitalne i - relativno neprecizne i nerealne - migracijske statistike pokazuju da Hrvatska demografski izumire, da gubi stanovništvo prirodnim i osobito mehaničkim putem te da se ne nazire usporavanje nego se, naprotiv, u brojčanim pokazateljima prepoznaje jačanje negativnih demografskih trendova. ${ }^{5}$ Utemeljena je tvrdnja da se Hrvatska, a osobito pojedine njezine regije, sve brže približava samom dnu demografske „provalije“ iz koje će biti nemoguće ili vrlo teško izaći. To više, jer nije riječ samo o „užoj“ demografskoj „recesiji“ bez značajnijih društvenih i ekonomskih implikacija nego upravo suprotno - radi se o društvenomu i gospodarskomu zaostajanju koje će samo akcelerirati njezino novo demografsko pražnjenje. Naime, izrazito jaka demografska regresija u kojoj se Hrvatska nalazi ima multiplikativan učinak na mnoge segmente javnoga života - od produbljenja prostorne populacijske i razvojne neravnoteže preko sve naglašenijega problema formiranja kontingenata radne snage pa do sve izraženijih poteškoća u društveno prihvatljivom funkcioniranju fondova zdravstvene, socijalne i napose mirovinske skrbi za hrvatske građane.

Iz dosadašnjih je znanstvenih analiza i rasprava poznato da je Hrvatska u demografskom i migracijskom kontekstu već stoljećima "otvoreno područje“, u koje su se ulijevale brojne useljeničke struje, ali i iz kojega se kontinuirano, i to u velikomu broju (privremeno i trajno), odlazilo u europske i prekomorske zemlje, ponajprije iz ekonomskih, ali i iz političkih, prirodno-geografskih, društvenih, kulturoloških ili kakvih drugih razloga. ${ }^{6}$ Procijenjeno je da se u posljednjih 120 -

4 Wertheimer-Baletić, Alica, 2017. Demografski procesi u Hrvatskoj i u zapadnoeuropskim zemljama - razlike, sličnosti i specifičnosti, Rad Hrvatske akademije znanosti i umjetnosti: Razred za društvene znanosti, 529, str. 9.

Prema službenim podatcima Hrvatska je na ime prirodnoga pada 2017. godine zabilježila gubitak od 16.921 stanovnika (36.566 živorođenih i 53.477 umrlih), dok je mehaničkim putem (negativan saldo ukupne migracije) izgubila još (najmanje) 37.799 stanovnika (15.553 doseljenih iz inozemstva i 47.352 odseljeno u inozemstvo). Ukupan demografski gubitak u 2017. godini, uz naznaku da podatci migracijske statistike nisu potpuni, iznosio je, dakle, 54.720 osoba, pri čemu je u ukupnoj depopulaciji prirodni pad stanovništva sudjelovao sa $30,9 \%$, a negativan saldo ukupne migracije sa $69,1 \%$. Prema privremenim rezultatima procjene broja stanovnika Hrvatska je na svršetku 2018 imala samo 4,089 milijuna stanovnika što je u odnosu na kraj 2017. godine smanjenje od gotovo 1,0\% (izvor: Migracija stanovništva Hrvatske u 2017., Priopćenje 7. 1. 2., DZSRH, Zagreb; Prirodno kretanje stanovništva u 2017. Statistička izvješća 1618, DZSRH, Zagreb, 2018; Publikacije prema statističkim područjima, Stanovništvo, Procjena stanovništva sredinom godine - privremeni podatci, DZSRH, Zagreb (www.dzs.hr; pristupljeno 20. ožujka 2019.)

6 Usp. Nejašmić, Ivo, 2014. Iseljavanje iz Hrvatske od 1900. do 2001.: demografske posljedice stoljetnog procesa, Migracijske i etničke teme, 30, 3, 405-435. Autor ističe da je "tijekom 20. stoljeća s teritorija današnje Republike Hrvatske neprekidno tekla široka rijeka iseljenika; iselilo se 2,3 milijuna ljudi“ (Nejašmić, 2014., str. 418). 
ak godina iz Hrvatske iselilo oko 2,8 milijuna osoba, a da je negativan saldo migracije iznosio približno 1,5 milijuna stanovnika. ${ }^{7}$ Ako navedenim brojkama pribrojimo i potencijalne gubitke nataliteta i prirodnoga prirasta iseljenoga stanovništva, onda je posve razvidno „da malobrojna hrvatska populacija ima zaista vrlo velike demografske gubitke zbog iseljavanja“.

No i u posljednjih nekoliko godina, zahvaljujući globalnoj (svjetskoj) gospodarskoj krizi, ekonomskoj i socijalnoj krizi u Hrvatskoj (osobito vidljivoj u porastu nezaposlenosti te $u$ povećanju nesigurnosti radnoga mjesta i egzistencijalne nesigurnosti mladih), ali i uslijed dovršetka integracijskoga procesa pristupanja Hrvatske Europskoj uniji (liberalizacija tržišta rada za hrvatske građane u većini zemalja EU), svjedočimo novom, i to brojčano izrazito jakom iseljeničkom valu koji odnosi ionako već znatno prorijeđene generacije hrvatskoga stanovništva nužne za reprodukciju. Zbog činjenice da u emigracijskom kontingentu više ne dominira "nižekvalificirani proizvodni radnik ${ }^{\prime \prime}{ }^{9}$ kako je to bilo od 1960-ih do kraja 1990-ih godina, nego da se, nasuprot tomu, posljednjih godina sve više iseljava mlađe visokoobrazovano stanovništvo, i to uglavnom cijele obitelji (uključujući sve veći broj djece, što indicira piramida starosti iseljenoga stanovništva), suvremena emigracija prijeti potpunim urušavanjem demografske, društvene i ekonomske „održivosti“ Hrvatske. Osnovno znanje o tom suvremenom „egzodusu" iz Hrvatske dostupno nam je i uglavnom poznato, barem na razini općih spoznajnih mjesta, ali nedostaju nam specifična znanja o stvarnim uzrocima i motivima odlaska, migracijskim aspiracijama mladih te o različitim vidovima iseljavanja, posebno kada je u pitanju (pre)oblikovanje kulturnoga, socijalnoga i nacionalnoga identiteta iseljenika. $U$ tomu smislu više su nego dobrodošla znanstvena (empirijska) istraživanja kojima bi se dublje i sveobuhvatnije osvijetlila pozadina suvremene migrantske problematike Hrvatske, osobito njezina vanjska migracija, ${ }^{10} \mathrm{i}$ to iz najmanje dva razloga: (1) zbog „okrnjenih“ i zapravo

7 Akrap, Strmota, Ivanda, 2017., str. 543; I. Nejašmić je procijenio glavne tokove i intenzitet iseljavanja iz Hrvatske u razdoblju 1900. - 2001. godine. Prema njegovoj procjeni iz Hrvatske je u tomu razdoblju iselilo 2,3 milijuna osoba, od kojih u periodu 1900. - 1948. njih 940 tisuća, od 1948. do 1991. 860 tisuća osoba te od 1991. do 2001. godine 500 tisuća stanovnika. Migracijsku bilancu za navedeno jednostoljetno razdoblje I. Nejašmić je procijenio na 1,2 milijuna stanovnika. Usp. Nejašmić, 2014., str. 419.

Akrap, Strmota, Ivanda, 2017., str. 543

9 Lajić, 2002., str. 139.

10

U tom smislu korisnim smatramo upozoriti na znanstveni rad T. Jurića o iseljavanju Hrvata u Njemačku te na zajednički rad M. Rajković Iveta i T. Horvatin o iseljavanju Hrvata u Irsku. Riječ je o državama u koje se, pridodajući im i Austriju, posljednjih godina najviše iseljava iz Hrvatske. Želeći istražiti „,kontekst i opseg suvremenog vala iseljavanja iz Hrvatske u Irsku te saznati kada je i zašto Irska postala popularno odredište hrvatskih građana, posebice mladih iz Slavonije" (Rajković Iveta, Marijeta, Horvatin, Tea, 2017. Suvremeno iseljavanje iz Hrvatske u Irsku s posebnim osvrtom na 
nerealnih službenih podataka migracijske statistike kojima raspolažemo i koji su u najvećoj mjeri bili podloga dosadašnjim istraživanjima, ali i (2) zbog nužnosti prepoznavanja stvarne migracijske motivacije koja treba poslužiti nositeljima upravljačkih struktura u Hrvatskoj na nacionalnoj i na lokalnoj razini kako bi prepoznali, osmislili i provodili one mjere javnih politika (demografske, socijalne, ekonomske, porezne, obiteljske i dr.) koje bi za cilj trebale imati usporavanje iseljavanja iz zemlje, ali i povratak iseljenih u nju. Ništa manje važna nisu ni pitanja iz kompleksa društvenih, ekonomskih, identitetskih, integracijskih i asimilacijskih izazova/posljedica ${ }^{11} \mathrm{~s}$ kojima se današnji hrvatski iseljenici suočavaju u odredišnim zemljama njihova iseljeničkoga puta. ${ }^{12}$

Imajući u vidu opći kontekst suvremene migrantske problematike u Hrvatskoj, predmet demografske analize u ovomu radu odrednice su i sastavnice ukupnoga kretanja stanovništva i demografske bilance Vukovarsko-srijemske županije (VSŽ) u razdoblju 2001. - 2017. godine, s posebnim naglaskom na mehaničku (migracijsku) komponentu ukupnoga kretanja stanovništva. Iz demograf-

mlade iz Slavonije, Migracijske i etničke teme, 33, 3, str. 248), autorice su pomoću etnološke i kulturnoantropološke kvalitativne metodologije, među ostalim, zaključile da „iako prevladavaju ekonomski čimbenici migracija, mnogi migranti iznijeli su i druge razloge za odlazak: osobna psihološka nezadovoljstva potaknuta nepotizmom i korumpiranosti od lokalne do nacionalne razine, neuvažavanje ljudskih prava odnosno konzervativna sredina, znatiželja itd.“ (Rajković Iveta, Horvatin, 2017, str. 268). Istražujući motivaciju Hrvata za iseljavanje u Njemačku, kombinirajući pritom kvalitativne i kvantitativne metodološke pristupe i postupke, T. Jurić, među ostalim, zaključuje „kako glavni motivi iseljavanja - prema percepciji samih iseljenika - nisu ekonomski. Analiza iseljeničkih stavova pokazala je da je glavni poticaj odlasku iz zemlje predodžba da u Hrvatskoj nisu institucionalizirane vrijednosti radne etike i uopće poštenja. Percepcija je iseljenika da se hrvatsko društvo moralno slomilo. Istraživanje upućuje na jasnu vezu između političke elite, slabih institucija i iseljavanja. (...) Istraživanje je pokazalo da su politička neizvjesnost i nestabilnost mnogima bile poticaj za odlazak. Većina traži sigurnost i uređen sustav. Svakako ne umanjujemo ni ekonomske motive iseljavanja, ali ih ne smatramo presudnima“" (Jurić, Tado, 2017. Suvremeno iseljavanje Hrvata u Njemačku: karakteristike i motivi, Migracijske i etničke teme, 33, 3, str. 362-363).

Tako, primjerice, I. Šola i M. Bičvić upozoravaju da se u kontekstu kauzalne raščlambe društveno aktualne problematike suvremenoga iseljavanja iz Hrvatske (tj. Slavonije koja je u prostornom smislu bila predmetom njihove znanstvene analize) uglavnom neopravdano zaobilaze psihološki, identitetski i etički aspekti, a prenaglašavaju ekonomski koji, dakako, nisu sekundarni, ali nisu niti jedini (usp. Šola, Ivica, Bičvić, Marijana. 2018. Ekonomsko iseljavanje iz Slavonije u SR Njemačku. Neka identitetska, psihološka i etička pitanja, Bogoslovska smotra, 88, 1, 157-175).

Suvremeno iseljavanje iz Hrvatske, kao uostalom i hrvatske iseljeničke struje u proteklim desetljećima pa i stoljećima, treba promatrati u kontekstu širih, odnosno globalnih zbivanja i trendova na europskoj i svjetskoj razini kada je u pitanju prostorna pokretljivost stanovništva. Uzroci i motivi suvremenoga iseljavanja iz Hrvatske dijelom slijede opći migracijski obrazac kod kojega dominiraju ekonomski čimbenici migracije, a dijelom dominiraju drugi činitelji uglavnom iz domene društvenih, političkih i drugih odnosa. U analizama globalnih migracija, s obzirom na sve složenije uzroke i teže i dugoročnije posljedice, u posljednje vrijeme osobitu pozornost zauzima sigurnosni aspekt, napose kada su u pitanju sve brojnije ilegalne ili nezakonite migracije. Usp. Vurnek, Dragutin, Bengez, Andrea, Perkov, Matej, 2018. Sigurnosni aspekti migracija, Acta Economica Et Turistica, 4, 2, 121-214. 
ske je literature poznato da je „ukupno kretanje stanovništva kao rezultat prirodnoga i mehaničkoga kretanja i vanjskih činitelja (ratova, gospodarskih kriza i sl.) polazište [je] $u$ analizi demografskih, društveno-gospodarskih, socijalnih i drugih promjena na određenom području“. ${ }^{13}$ Svrha je istraživanja stoga (1) utvrditi veličinu i strukturu demografske bilance, (2) komparativnom vitalnostatističkom metodom procijeniti grubu migracijsku bilancu te (3) vrednovati utjecaj suvremene migracije na ukupno kretanje i razvoj stanovništva Vukovarsko-srijemske županije kroz tematizirano razdoblje (ukupno te na razini jedinica lokalne samouprave - gradova i općina) s općim ciljem prepoznavanja dominantnih suvremenih dinamičkih obilježja njezina sadašnjega demografskoga razvoja.

Uvodno je potrebno naznačiti da je od 179.521 stanovnika Vukovarsko-srijemske županije popisanoga 2011. godine, njih 78.208 ili 43,6\% od rođenja živjelo u naselju popisa, dok je iz drugih hrvatskih županija i iz inozemstva u Županiju doseljeno ukupno 61.116 stanovnika, što je zamjetnih 34,0\% ukupnoga stanovništva Županije. U unutaržupanijskim preseljavanjima, između gradova, općina i naselja Vukovarsko-srijemske županije, migriralo je dodatnih 40.105 osoba ili 22,3\% ukupnoga stanovništva Županije. Od ukupnoga broja doseljenih (61.116), iz drugih su se hrvatskih županija doselila 31.022 stanovnika (17,3\% ukupnoga stanovništva Županije), a iz inozemstva 30.094 osobe (16,8\% ukupnoga stanovništva Županije), među kojima su daleko najbrojniji bili doseljenici iz Bosne i Hercegovine (17.220), Njemačke (4.946) i Srbije (4.509). Predočeni popisni podatci ukazuju na dugoročnu važnost migracijske komponente, odnosno unutarnjih (unutarhrvatskih i unutaržupanijskih) i vanjskih migracija u formiranju trenutne naseljenosti u Vukovarsko-srijemskoj županiji. Navedeni podatci, iako se odnose na kritični vremenski trenutak popisa 2011. godine (31. ožujka / 1. travnja), odraz su dugoročne dinamike prostorne pokretljivosti stanovništva kroz prošla međupopisna razdoblja, što u velikoj mjeri korespondira s migracijskim tipom formiranja naseljenosti, neovisno o prevladavajućem predznaku smjera migracijske bilance.

$\overline{13}$ Wertheimer-Baletić, Alica, Akrap, Anđelko, 2008. Razvoj stanovništva Vukovarsko-srijemske županije s posebnim osvrtom na ekonomsku strukturu od 1971. do 2001., Društvena istraživanja, 17, 1-2, str. 52. 


\section{METODOLOŠKA POJAŠNJENJA}

Kao i u svakoj demografskoj analizi koja obuhvaća raščlambu, prikaz i interpretaciju podataka popisne, vitalne i migracijske statistike, potrebno je dati osnovna metodološka pojašnjenja kako bi se na ispravan način razumjeli prostorni i vremenski okvir provedene analize te brojčana argumentacija iznesenih zaključaka.

Prostorni se okvir analize u ovomu radu odnosi na područje Vukovarskosrijemske županije, uspostavljene krajem 1992. godine od teritorija bivših općina Vukovar, ${ }^{14}$ Vinkovci i Županja. Na $2.454 \mathrm{~km}^{2}$ (4,3\% kopnene površine RH), živio je, prema posljednjemu popisu iz 2011. godine, ukupno 179.521 stanovnik $(4,2 \%$ ukupnoga stanovništva RH), što znači da je Vukovarsko-srijemska županija sa 73,2 stan./ $\mathrm{km}^{2}$ bila ispodprosječno naseljena hrvatska županija, od koje su, u Republici Hrvatskoj $(75,7)$ veću opću relativnu gustoću naseljenosti imale županije: Zagrebačka $(103,8)$, Krapinsko-zagorska $(108,1)$, Varaždinska $(139,4)$, Primorskogoranska (82,6), Brodsko-posavska (78,1), Osječko-baranjska (73,4), Splitsko-dalmatinska $(100,2)$, Istarska $(74,0)$, Međimurska $(156,1)$ i - dakako - Grad Zagreb $(1.232,5)$. Od Vukovarsko-srijemske županije rjeđe su naseljene bile ove županije: Sisačko-moslavačka $(38,6)$, Karlovačka $(35,6)$, Koprivničko-križevačka $(66,1)$, Bjelovarsko-bilogorska $(45,4)$, Virovitičko-podravska (41,9), Požeško-slavonska $(42,8)$, Zadarska $(46,6)$, Šibensko-kninska $(36,7)$, Dubrovačko-neretvanska $(68,8)$ i - dakako - Ličko-senjska županija ${ }^{15}$ (svega 9,5 stan. $/ \mathrm{km}^{2}$ ). U administrativnom smislu Vukovarsko-srijemska županija podijeljena je na ukupno 31 jedinicu lokalne samouprave: 5 jedinica sa statusom grada (Ilok, Otok, Vinkovci, Vukovar i Županja) i 26 jedinica sa statusom općine. ${ }^{16} \mathrm{U}$ njima se nalaze ukupno 84 naselja sa stalno popisanim stanovništvom, što implicira prosječnu naseljenost na razini naselja 2011. godine od 2.137 stanovnika. ${ }^{17}$

$\overline{14}$ Izuzetak je samo naselje Klisa koja je iz sjeverozapadnoga dijela bivše općine Vukovar ušla u sastav Grada Osijeka i Osječko-baranjske županije.

15 Izvor: Popis stanovništva 2011., Županije, površina, stanovništvo, gradovi, općine i naselja, DZSRH, Zagreb (www.dzs.hr; pristupljeno 6. ožujka 2019.).

16 U Vukovarsko-srijemskoj županiji ustrojene su općine (abecednim redom): Andrijaševci, Babina Greda, Bogdanovci, Borovo, Bošnjaci, Cerna, Drenovci, Gradište, Gunja, Ivankovo, Jarmina, Lovas, Markušica, Negoslavci, Nijemci, Nuštar, Privlaka, Stari Jankovci, Stari Mikanovci, Štitar, Tompojevci, Tordinci, Tovarnik, Trpinja, Vođinci i Vrbanja.

17 Tek usporedbe radi prosječna naseljenost u Hrvatskoj iznosila je prema rezultatima popisa i stanju naselja 2011. godine 634 stanovnika po jednom naselju. 
Vremenski okvir ove analize uokviren je rezultatima popisa stanovništva 2001. godine te podatcima vitalne i migracijske statistike za 2017. godinu. ${ }^{18}$ To znači da vremenski okvir provedene demografske analize uključuje jedno „cjelovito“ međupopisje (2001. - 2011.) i jedno „krnje“ međupopisno razdoblje (2011. 2017.) koje tek 2021. godine treba biti „,zatvoreno“ novim popisom stanovništva.

$\mathrm{U}$ uvodu je istaknuto da su predmet demografske analize $\mathrm{u}$ ovomu radu odrednice i sastavnice ukupnoga kretanja stanovništva i demografske bilance Vukovarsko-srijemske županije od popisa 2001. do 2017. godine. Osnovni statistički izraz ukupnoga kretanja stanovništva kao sumarnoga ili agregatnoga pokazatelja jest međupopisna promjena broja stanovnika koja se može iskazati u apsolutnim i/ili u relativnim vrijednostima (indeksi i stope). Ovisno o predznaku smjera međupopisne promjene, ukupno kretanje stanovništva može biti pozitivno (demografski porast), negativno (demografski pad ili ukupna depopulacija) i stagnantno (bez statistički značajnijega porasta ili pada broja stanovnika). Pozitivan, negativan ili stagnantan trend ukupnoga kretanja stanovništva determiniran je kvantitativnim međuodnosom između dviju dinamičkih odrednica demografskoga razvoja (prirodnoga i mehaničkoga kretanja), tj. određen je aktivom i pasivom demografske bilance, pri čemu su sastavnice aktive demografske bilance natalitet/fertilitet i imigracija, a sastavnice pasive demografske bilance mortalitet i emigracija. Predznak smjera ukupnoga kretanja stanovništva rezultat je diferencijalne strukture sastavnica demografske bilance. U tomu kontekstu vrijednosti aktive i pasive demografske bilance signifikantan su pokazatelj utjecaja različitih endogenih (demografskih) i eksternih (socijalnih, ekonomskih, obrazovnih, povijesnih, prostorno-geografskih i drugih) čimbenika demografskoga razvoja, od kojih mnogi u danim okolnostima imaju dugoročan destabilizacijski učinak. ${ }^{19}$

Analizu promjene broja stanovnika kao agregatnoga izraza ukupnoga kretanja stanovništva Vukovarsko-srijemske županije zasnivali smo na rezultatima popisa stanovništva 2001. i 2011. godine prema kriteriju prisutnosti ili stanovništva „u zemlji“. S obzirom na to da su popisi 2001. i 2011. godine, premda su u metodološkom smislu oba bila utemeljena na konceptu/kriteriju "uobičajenoga mjesta stanovanja“, provedeni prema različitim definicijama kategorije ukupnoga stanovništva, to ne postoji potpuna ili izravna usporedivost njihovih službenih rezultata. Stoga smo korigirali službeni broj stanovnika 2001.

\footnotetext{
$\overline{18}$ U vremenu provedbe istraživanja nisu bili dostupni službeni i konačni (cjeloviti) podatci vitalne i migracijske statistike Državnoga zavoda za statistiku RH za 2018. godinu. Njihovo se objavljivanje očekuje sredinom 2019. godine.

19

Detaljnije u: Wertheimer-Baletić, 2017.
} 
godine te ga sveli na kontingent stanovništva „u zemlji“, isključujući iz analize popisane hrvatske građane $u$ inozemstvu (na radu, kao članovi obitelji ili kao diplomatsko-konzularno osoblje i članovi njihovih obitelji), a njih je 2001. godine u Županiji bilo 18.060 ili 8,8\% ukupnoga stanovništva. Sukladno metodologiji popisa i tada primijenjenoj definiciji ukupnoga stanovništva, 2011. godine nisu popisivani hrvatski građani u inozemstvu (izuzev onih koji su se barem jednom tjedno vraćali u Hrvatsku, a i oni nisu posebno iskazani u objavljenim rezultatima popisa). To znači da bi, barem donekle, stanovništvo „u zemlji“ iz popisa 2001. bilo usporedivo s ukupnim brojem stanovnika iz popisa 2011. godine. Razlog za navedenu korekciju pronalazimo i u činjenici da se podatci o rađanjima i umiranjima u Hrvatskoj od 1998. godine prikupljaju i objavljuju samo za prisutno stanovništvo, dakle bez vitalnih događaja (rađanja i umiranja) hrvatskih građana na radu ili boravku u inozemstvu.

U svrhu analize prirodnoga kretanja stanovništva Vukovarsko-srijemske županije uspostavili smo usporedivu vremensku seriju podataka vitalne statistike od 2001. do zaključno 2017. godine. Na temelju podataka o broju živorođene djece i umrlih osoba, na godišnjoj smo razini utvrdili prirodnu promjenu te na osnovi procjene broja stanovnika Županijesredinom svake godine $\mathrm{u}$ promatranomu razdoblju izračunali stope nataliteta, mortaliteta i prirodne promjene (iskazane u promilima). Ujedno, usporedbom apsolutnih vrijednosti nataliteta $\mathrm{i}$ mortaliteta izračunali smo vitalni indeks kao jednostavan, ali vrlo indikativan pokazatelj opadajuće, stagnantne ili proširene bioreprodukcije stanovništva.

Za ocjenu utjecaja migracijske komponente na ukupno kretanje stanovništva i demografsku bilancu Vukovarsko-srijemske županije uspostavili smo usporedivu seriju podataka migracijske statistike ${ }^{20}$ za razdoblje 2001. - 2017. godine. $S$ obzirom na metodologiju prikupljanja, obrade i objavljivanja podataka hrvatske migracijske statistike izneseni su podatci na godišnjoj razini međusobno usporedivi. No, generalno uzevši, oni ne odražavaju realno stanje u kontekstu prostorne pokretljivosti stanovništva Županije, osobito kada je u pitanju vanjska migracija. Naime, unutarnja ${ }^{21}$ i vanjska ${ }^{22}$ migracija stanovništva Hrvatske,

$\overline{20}$ Prema Metodološkim objašnjenjima DZSRH (www.dzs.hr, stranici pristupljeno 14. siječnja 2019.) "doseljenim, odnosno odseljenim stanovništvom smatra se stanovništvo koje je promijenilo uobičajeno mjesto stanovanja na području Republike Hrvatske ili koje je promijenilo uobičajenu državu stanovanja na razdoblje koje je ili se očekuje da će biti dugo najmanje godinu dana“.

Prema Metodološkim objašnjenjima DZSRH (www.dzs.hr, stranici pristupljeno 14. siječnja 2019.) „statistika unutarnje migracije stanovništva prikuplja i obrađuje podatke o tijekovima migracije stanovništva unutar zemlje, tj. o broju i strukturi osoba koje su promijenile mjesto stanovanja unutar Republike Hrvatske u određenoj kalendarskoj godini“.

Prema Metodološkim objašnjenjima DZSRH (www.dzs.hr, stranici pristupljeno 14. siječnja 2019.) ,statistika vanjske migracije stanovništva prikuplja i obrađuje podatke o tijekovima vanjske migracije, tj. o broju i strukturi osoba koje su promijenile uobičajenu državu stanovanja u određenoj kalendarskoj godini“. 
pa tako i Vukovarsko-srijemske županije, koju na godišnjoj razini objavljuje DZSRH, temelji se na evidenciji Ministarstva unutarnjih poslova o prijavi i odjavi prebivališta. Premda važeći Zakon o prebivalištu predviđa obvezu svake osobe da prilikom iseljenja iz zemlje, neovisno o trajnosti ili privremenosti odlaska, odjavi svoje prebivalište (bilo u nadležnoj policijskoj upravi ili policijskoj postaji, bilo u diplomatsko-konzularnom predstavništvu Republike Hrvatske u inozemstvu) ${ }^{23}$ određeni broj hrvatskih građana iz različitih razloga to ne čini, tako da je službeni evidencijski obuhvat iseljeničkoga kontingenta "okrnjen“; drugim riječima, manji je od stvarnoga. Dok se, dakle, za brojčane pokazatelje unutaržupanijske i unutarhrvatske migracije drži da uglavnom predstavljaju objektivno stanje na terenu, dotle se za brojčane pokazatelje vanjske migracije smatra da nisu odraz realnoga stanja, tj. da oni precjenjuju broj doseljenih iz inozemstva u Hrvatsku (i u Vukovarsko-srijemsku županiju), a osobito podcjenjuju broj iseljenih iz Hrvatske (dakako, i iz Vukovarsko-srijemske županije) u inozemstvo. Koliki je odnos između stvarnoga stanja i službenoga broja vanjskih migranata, nepoznato je. U nedavno objavljenom istraživanju, autori (I. Draženović, M. Kunovac i D. Pripužić) procijenili su da je stvarni broj iseljenih iz Hrvatske u zemlje Europske unije u razdoblju 2013. - 2016. godine približno 2,6 puta veći od službenih brojki hrvatske migracijske statistike. Prema podatcima DZSRH, ukupni broj iseljenih iz Hrvatske u tomu je razdoblju dosegnuo 102.207 stanovnika, dok je - prema procjeni autora studije na koju se referiramo, izrađene na temelju statističkih izvora zemalja useljenja - stvarni broj iseljenih iz Hrvatske 269.786 osoba. ${ }^{24}$ Imajući naprijed navedeno u vidu, s oprezom treba koristiti i interpretirati službene podatke hrvatske migracijske statistike. ${ }^{25}$ No u nedostatku pouzdanije migracijske statistike i službeni su podatci DZSRH iskoristivi i indi-

$$
\text { emigration: the case of Croatia and the experience of new EU member states, Public Sector Economics, }
$$
42, 4, 415-447.

Tako i N. Pokos upozorava na signifikantnu razliku između službenoga broja iseljenih iz Hrvatske $\mathrm{u}$ inozemstvo koje publicira DZSRH i broja doseljenih hrvatskih državljana ili hrvatskih građana u pojedine zemlje Europske unije. Primjetan je veliki nerazmjer koji se, smatra N. Pokos, može/treba objasniti dvama uzrocima: prvo, činjenicom da, statistički gledano, broj doseljenih u neke zemlje, npr. Njemačku i Austriju, obuhvaća ne samo hrvatske građane nego i kategoriju hrvatskih državljana, što znači da ne podrazumijeva samo doseljenike iz Hrvatske nego i iz drugih zemalja (ponajviše iz Bosne i Hercegovine) koji imaju hrvatsko državljanstvo; drugo, već istaknutom činjenicom da svi iz Hrvatske prilikom privremenoga ili trajnoga iseljenja ne odjavljuju svoje prebivalište u Republici Hrvatskoj (usp. Pokos, 2017). Razlike u broju iseljenih u Irsku između podataka koje objavljuje DZSRH i službenih podataka irskoga Vladinoga ureda za zapošljavanje i socijalnu zaštitu, utvrdile su i M. Rajković Iveta i T. Horvatin. Tako je 2016. godine, prema objavljenim podatcima DZSRH, u Irsku iselilo 1.915 hrvatskih građana, dok je iste godine, prema naprijed navedenom irskom izvoru, u tu zemlju uselilo 5.312 hrvatskih građana (usp. Rajković Iveta, Horvatin, 2017, str. 254), dakle, gotovo tri puta više! 
kativni $\mathrm{u}$ određivanju predznaka salda ukupne migracije te $\mathrm{u}$ procjeni veličine i strukture demografske bilance Vukovarsko-srijemske županije. Iz naprijed je navedenih razloga procijenjena demografska bilanca Županije za razdoblje od 2011. do kraja 2017. godine vjerojatno zamjetno povoljnija u odnosu na stvarno stanje, koje još uvijek ne možemo egzaktno utvrditi bez dodatnih terenskih istraživanja ili registra stanovništva, ali moramo biti svjesni složenosti i dubine demografske krize u kojoj se Županija i njezine administrativne jedinice nalaze i za koju je formalna statističko-matematička potvrda tek dijelom moguća. Iz navedenih smo razloga, za međupopisje 2001. - 2011. godine, primjenom komparativne vitalnostatističke metode, na osnovi međupopisne promjene broja stanovnika i prirodne promjene stanovništva Vukovarsko-srijemske županije $u$ tomu desetljeću, prema kriteriju prisutnosti (stanovništva „u zemlji“) izračunali (procijenili) i njezinu grubu migracijsku bilancu.

\section{UKUPNO KRETANJE STANOVNIŠTVA}

\subsection{Promjena broja stanovnika (,u zemlji“) 2001. - 2011. godine}

Prema formalnim demografsko-statističkim kriterijima, ukupna depopulacija dominantan je opći dinamički demografski proces u Vukovarsko-srijemskoj županiji kao i u većini njezinih administrativnih jedinica (gradova/općina). U promatranom je međupopisnomu razdoblju (2001. - 2011.) opća reprodukcija stanovništva Vukovarsko-srijemske županije bila negativna, što indiciraju, s jedne strane, izračunati indeks međupopisne promjene broja stanovnika kao agregatnoga ili sumarnoga statističkoga izraza ukupnoga kretanja stanovništva te, s druge strane, utvrđeni tip intenziteta međupopisne promjene. ${ }^{26}$ Između 2001. i 2011. godine broj stanovnika u Županiji, prema kriteriju prisutnosti ili stanovništva „u zemlji“, smanjen je sa $186.185^{27}$ na 179.521 osobu ili za $3,6 \%$, što indicira osrednju depopulaciju kao regresivni tip intenziteta međupopisne promjene (tablica 1). Negativna opća reprodukcija u međupopisju 2001. - 2011. godine nastavak je jakoga depopulacijskoga trenda iz prethodnoga međupopisnoga razdoblja (1991. - 2001.) tijekom kojega je broj stanovnika „u zemlji“ u Županiji smanjen s $214.658^{28}$ na 186.185 osoba, što znači da je stopa ukupne depopulacije

\footnotetext{
26 Tip intenziteta međupopisne promjene broja stanovnika određen je prema modelu koji je postavio I. Nejašmić (usp. Nejašmić, Ivo, 2005. Demogeografija - stanovništvo u prostornim odnosima i procesima, Zagreb: Školska knjiga).

27 Popisom utvrđeni ukupni broj stanovnika Vukovarsko-srijemske županije 2001. godine iznosio je 204.768, što znači da je „u zemlji“ tada živjelo 90,9\% njezinoga ukupnoga stanovništva.

28 Popisom utvrđeni ukupan broj stanovnika Vukovarsko-srijemske županije 1991. godine iznosio je 231.241, što znači da je „u zemlji“ tada živjelo 92,8\%, a u inozemstvu 7,2\% njezinoga ukupnoga stanovništva.
} 
iznosila čak $-13,3 \%$, što je bilo signifikantno niže od državnoga prosjeka $(-6,6 \%)^{29}$ Tip intenziteta međupopisne promjene između 1991. i 2001. godine bio je najnepovoljniji - izumiranje. Visoki demografski ratni gubitci u Domovinskom ratu (ratni mortalitet i prisilne migracije) ${ }^{30}$ osnažili su naslijeđene - iako još uvijek pozitivne, no ipak sve nepovoljnije - trendove u bioreprodukciji i mehaničkomu kretanju stanovništva te demografskim strukturama, snažno progredirajući demografsko starenje. ${ }^{31}$ Nakon gotovo kontinuiranoga demografskoga porasta od prvoga modernoga popisa stanovništva 1857. do posljednjega prije Domovinskoga

$\overline{29}$ Korisno je na ovomu mjestu donijeti nešto širi izvadak iz istraživanja I. Lajića i S. Klempić Bogadi koji su, u sklopu šire istraživačke teme, analizirajući pritom i suvremene demografske prilike u Vukovarsko-srijemskoj županiji, upozorili da je više nego očito da se „dio raseljenog stanovništva (Hrvata ali i Srba) nije vratio ovamo ni nakon mirne reintegracije te infrastrukturne i stambene obnove porušenih objekata koju je financirala država. Brojni su razlozi za takvu situaciju. Dugotrajnost prognaništva i izbjeglištva učinila je da se dio njih, posebice mlađih stanovnika prilagodio životu u novoj sredini i ne želi se vratiti. Za dio stanovništva razlozi su emocionalne i psihološke prirode, zbog čega nisu spremni ponovno ovdje živjeti. Razloge možemo pronaći i u propasti industrije i nestanku brojnih radnih mjesta pa se tako Vukovar, koji je nekada bio najjači ekonomski centar regije, nije uspio gospodarski oporaviti, dok su istovremeno Vinkovci zbog brojnih problema tranzicijskoga gospodarstva također ekonomski slabjeli“ (Klempić Bogadi, Sanja, Lajić, Ivan, 2014. Suvremena migracijska obilježja statističkih jedinica Republike Hrvatske, Migracijske i etničke teme, 30, 3, str. 448)

Detaljnije vidjeti u: Živić, Dražen, Turk, Ivo, 2011. Demografski gubitci Vukovarsko-srijemske županije u Hrvatskom domovinskom i obrambenom ratu, u: Žrtva znak vremena. Zbornik radova Petog hrvatskog žrtvoslovnog kongresa (Šeparović, Zvornimir, ur.), Zagreb: Hrvatsko žrtvoslovno društvo, 542-554. Autori su ukupne demografske ratne gubitke Vukovarsko-srijemske županije procijenili na 41 tisuću stanovnika. Zbog necjelovite ratne statistike još uvijek nije moguće utvrditi konačnu demografsku bilancu ukupnih i parcijalnih ratnih gubitaka Vukovarsko-srijemske županije.

O najvažnijim odrednicama, obilježjima, trendovima i strukturama u kretanju stanovništva i razvoju naseljenosti na području današnje Vukovarsko-srijemske županije od prvoga modernoga popisa 1857. godine naovamo detaljnije vidjeti (abecednim redom) u: Pejaković, Tomislav, 2016. Biološki sastav i starenje stanovništva Vukovarsko-srijemske županije 1961. - 2011. godine, Hrvatski geografski glasnik, 78, 1, 125-158; Wertheimer-Baletić, Alica, 1993.a. Jedno i pol stoljeće u brojčanom razvoju stanovništva Vukovara i vukovarskoga kraja, Društvena istraživanja, 2, 4-5, 455-477; Wertheimer-Baletić, Alica, 1993.b. Stanovništvo Vukovara i vukovarskog kraja, Zagreb: Nakladni zavod Globus; Wertheimer-Baletić, Alica, 1997. Razvoj stanovništva Vukovara (1857. - 1991.), u: Zbornik radova o Vukovarsko-srijemskoj županiji (Klepac, Dušan i Čorkalo, Katica ur.), Vinkovci: Hrvatska akademija znanosti i umjetnosti. Centar za znanstveni rad Vinkovci, 41-62; Wertheimer-Baletić, Alica, Akrap, Anđelko, 2008., 51-75; Živić, Dražen, 2006. Stanovništvo Vukovarsko-srijemske županije (odrednice i obilježja demografskih promjena od sredine 19. do početka 21. stoljeća), Zagreb - Vukovar: Institut društvenih znanosti Ivo Pilar, Ogranak Matice hrvatske u Vukovaru; Živić, Dražen, 2012. Stanovništvo Vukovarsko-srijemske županije - procesi, trendovi i perspektive, u: Vukovarsko-srijemska županija - prostor, ljudi, identitet (Živić, Dražen, ur.), Vukovar - Zagreb: Vukovarsko-srijemska županija i Institut društvenih znanosti Ivo Pilar, 27-54; Živić, Dražen, Turk, Ivo, Šimunić, Nikola, 2017. Demografske promjene u Vukovarsko-srijemskoj županiji (2001. - 2014.) u zrcalu nacionalne sigurnosti, u: Domovinska (i europska) sigurnost. Kriza sigurnosti i politike manipuliranja suverenitetom (Cvikić, Sandra, Žebec Šilj, Ivana, Bendra, Ivana, ur.), Zagreb - Vukovar: Institut društvenih znanosti Ivo Pilar, 39-72. 
rata 1991., ${ }^{32}$ Vukovarsko-srijemska županija početkom 1990-ih ušla je u razdoblje kontinuirane ukupne depopulacije koja se, prema svemu sudeći, nesmanjenim intenzitetom nastavila i nakon posljednjega popisa stanovništva 2011. godine. ${ }^{33}$

Međupopisnu promjenu broja stanovnika Vukovarsko-srijemske županije na razini jedinica lokalne samouprave u razdoblju 2001. - 2011. godine donosimo $u$ tablici 1. Komparativna analiza pokazuje da se većina $(71,0 \%)$ administrativnih jedinica Županije nalazi u procesu ukupne depopulacije različitoga intenziteta: 3 jedinice (Babina Greda, Ivankovo i Jarmina) karakterizira slaba depopulacija, 7 jedinica (Vukovar, Bošnjaci, Gradište, Markušica, Privlaka, Stari Mikanovci i Tordinci) karakterizira osrednja depopulacija, 6 jedinica (Otok, Gunja, Stari Jankovci, Tovarnik i Trpinja) karakterizira jaka depopulacija te 6 jedinica (Ilok, Bogdanovci, Drenovci, Lovas, Nijemci i Tompojevci) karakterizira najnepovoljniji tip intenziteta međupopisne promjene - izumiranje. U gradovima/općinama s regresivnim značajkama međupopisne promjene smanjenje broja stanovnika između 2001. i 2011. godine iznosilo je $-7,7 \%$ (sa 115.967 na 107.042 stanovnika). Nasuprot „depopulacijskim“ jedinicama lokalne samouprave, samo 7 gradova/ općina u Vukovarsko-srijemskoj županiji (malo više od petine - 22,6\% svih administrativnih jedinica županije) ostvarilo je između 2001. i 2011. godine porast broja stanovnika (,u zemlji“), i to ukupno sa 61.565 na 64.809 osoba ili za nevelikih $5,3 \%$, uz napomenu da je 5 jedinica (Vinkovci, Županja, Negoslavci, Nuštar i Vođinci) imalo osrednju, a 2 jedinice (Borovo i Štitar) slabu progresiju kao tip intenziteta međupopisne promjene. Općine Andrijaševci i Cerna u posljednjemu su međupopisju imale stagnaciju kao tip intenziteta međupopisne promjene, jer je u njima broj stanovnika (,u zemlji“) između 2001. i 2011. godine ukupno porastao s 8.654 na 8.670 ili za neznatnih $0,2 \%$. Korisno je naznačiti da su gradovi kao administrativne jedinice Vukovarsko-srijemske županije imali slabu $(-2,1 \%)$, a općine osrednju depopulaciju $(-5,0 \%)$ kao tip intenziteta međupopisne promjene broja stanovnika (,u zemlji“).

\footnotetext{
32 Ukupan broj stanovnika u Vukovarsko-srijemskoj županiji smanjen je samo u međupopisju između 1910. i 1921. godine, i to zahvaljujući ponajviše visokim ljudskim i migracijskim demografskim gubitcima uzrokovanima Prvim svjetskim ratom i njegovim kompleksnim društvenim, političkim, ekonomskim i drugim posljedicama.

Ne ulazeći detaljnije u analizu demografskih trendova prije 2001. godine korisno je ipak istaknuti nekoliko istraživačkih nalaza do kojih su došli A. Wertheimer-.Baletić i A. Akrap. Oni su konstatirali da je s popisom 1971. godine završilo razdoblje iznadprosječnoga demografskoga porasta $u$ Vukovarsko-srijemskoj županiji, započeto agrarnom reformom i kolonizacijama nakon Drugoga svjetskoga rata, a da su na ukupne i strukturne promjene u razvoju stanovništva nakon 1971., uz opće modernizacijske čimbenike, djelovali i specifični čimbenici, ponajprije ubrzani procesi deagrarizacije i deruralizacije, koji su uvjetovali zamjetan odljev stanovništva te velikosrpska ratna agresija 1990-ih godina. Usp. Wertheimer-Baletić, Akrap, 2008.
} 
Naprijed izneseni brojčani podatci i pokazatelji impliciraju zaključak o dominantnim depopulacijskim dinamičkim obilježjima Vukovarsko-srijemske županije, ali i snažno upozoravaju na relativnu prostornu homogenost depopulacijskih obilježja u općoj reprodukciji stanovništva. Naime, u općinama/gradovima s regresijskim značajkama brojčane (popisne) dinamike stanovništva prema kriteriju prisutnosti 2001. godine živjelo je 62,6\%, a 2011. nešto manje - 59,6\%, no još uvijek zamjetno više od polovice ukupnoga stanovništva Vukovarsko-srijemske županije. Porast relativnoga udjela stanovništva u administrativnim jedinicama s demografskom ekspanzijom može se pripisati samo međupopisnomu porastu broja stanovnika u gradovima Vinkovci i Županja. Uvjetno rečeno, pretežno ruralne administrativne jedinice $u$ Vukovarsko-srijemskoj županiji imaju (donekle) izraženije demografsko pražnjenje u odnosu na pretežno urbane sredine, što posrednim putem signalizira važnost migracijske komponente u ukupnomu kretanju stanovništva, odnosno u oblikovanju strukture demografske bilance Vukovarsko-srijemske županije kroz analizirano razdoblje.

Tablica 1. Međupopisna promjena broja stanovnika Vukovarsko-srijemske županije (2001. - 2011.) po gradovima/općinama prema konceptu prisutnoga stanovništva iz 2001. i ukupnoga broja stanovnika iz popisa 2011. godine

\begin{tabular}{|l|c|c|c|c|l|}
\hline \multicolumn{1}{|c|}{ Grad/općina } & 2001. & 2011. & $\begin{array}{c}\text { Apsolutna } \\
\text { promjena }\end{array}$ & $\begin{array}{c}\text { Indeks } \\
\text { promjene }\end{array}$ & \multicolumn{1}{|c|}{ Tip promjene } \\
\hline Ilok & 7778 & 6767 & -1011 & 87,0 & Izumiranje \\
\hline Otok & 6873 & 6343 & -530 & 92,3 & Jaka depopulacija \\
\hline Vinkovci & 34156 & 35312 & 1156 & 103,4 & Osrednja progresija \\
\hline Vukovar & 29587 & 27683 & -1904 & 93,6 & Osrednja depopulacija \\
\hline Županja & 11666 & 12090 & 424 & 103,6 & Osrednja progresija \\
\hline Gradovi ukupno & 90060 & 88195 & -1865 & 97,9 & Slaba depopulacija \\
\hline Andrijaševci & 4065 & 4075 & 10 & 100,2 & Stagnacija \\
\hline Babina Greda & 3614 & 3572 & -42 & 98,8 & Slaba depopulacija \\
\hline Bogdanovci & 2231 & 1960 & -271 & 87,9 & Izumiranje \\
\hline Borovo & 4933 & 5056 & 123 & 102,5 & Slaba progresija \\
\hline Bošnjaci & 4048 & 3901 & -147 & 96,4 & Osrednja depopulacija \\
\hline
\end{tabular}


Rad Hrvat. akad. znan. i umjet. Razred za druš. znan. 54=539(2019) : 163-201

Dražen Živić: Migracijska komponenta ukupnoga kretanja stanovništva Vukovarsko-srijemske županije 2001. - 2017.

\begin{tabular}{|c|c|c|c|c|c|}
\hline Cerna & 4589 & 4595 & 6 & 100,1 & Stagnacija \\
\hline Drenovci & 5888 & 5174 & 585 & 87,9 & Izumiranje \\
\hline Gradište & 2949 & 2773 & -176 & 94,0 & Osrednja depopulacija \\
\hline Gunja & 4132 & 3732 & -400 & 90,3 & Jaka depopulacija \\
\hline Ivankovo & 8104 & 8006 & -98 & 98,8 & Slaba depopulacija \\
\hline Jarmina & 2490 & 2458 & -32 & 98,7 & Slaba depopulacija \\
\hline Lovas & 1507 & 1214 & -293 & 80,6 & Izumiranje \\
\hline Markušica & 2727 & 2555 & -172 & 93,7 & Osrednja depopulacija \\
\hline Negoslavci & 1395 & 1463 & 68 & 104,9 & Osrednja progresija \\
\hline Nijemci & 5404 & 4705 & -699 & 87,1 & Izumiranje \\
\hline Nuštar & 5418 & 5793 & 375 & 106,9 & Osrednja progresija \\
\hline Privlaka & 3126 & 2954 & -172 & 94,5 & Osrednja depopulacija \\
\hline Stari Jankovci & 4796 & 4405 & -391 & 91,8 & Jaka depopulacija \\
\hline Stari Mikanovci & 3107 & 2956 & -151 & 95,1 & Osrednja depopulacija \\
\hline Štitar & 2097 & 2129 & 32 & 101,5 & Slaba progresija \\
\hline Tompojevci & 1885 & 1565 & -320 & 83,0 & Izumiranje \\
\hline Tordinci & 2126 & 2032 & -94 & 95,6 & Osrednja depopulacija \\
\hline Tovarnik & 3088 & 2775 & -313 & 89,9 & Jaka depopulacija \\
\hline Trpinja & 6143 & 5572 & -571 & 90,7 & Jaka depopulacija \\
\hline Vođinci & 1900 & 1966 & 66 & 103,5 & Osrednja progresija \\
\hline Vrbanja & 4364 & 3940 & -424 & 90,3 & Jaka depopulacija \\
\hline Općine ukupno & 96125 & 91326 & -4799 & 95,0 & Osrednja depopulacija \\
\hline Županija ukupno & 186185 & 179521 & -6664 & 96,4 & Osrednja depopulacija \\
\hline
\end{tabular}

Izvor: Popisi stanovništva 2001. i 2011., DZSRH, Zagreb

(www.dzs.hr; pristupljeno 20. veljače 2019.). 


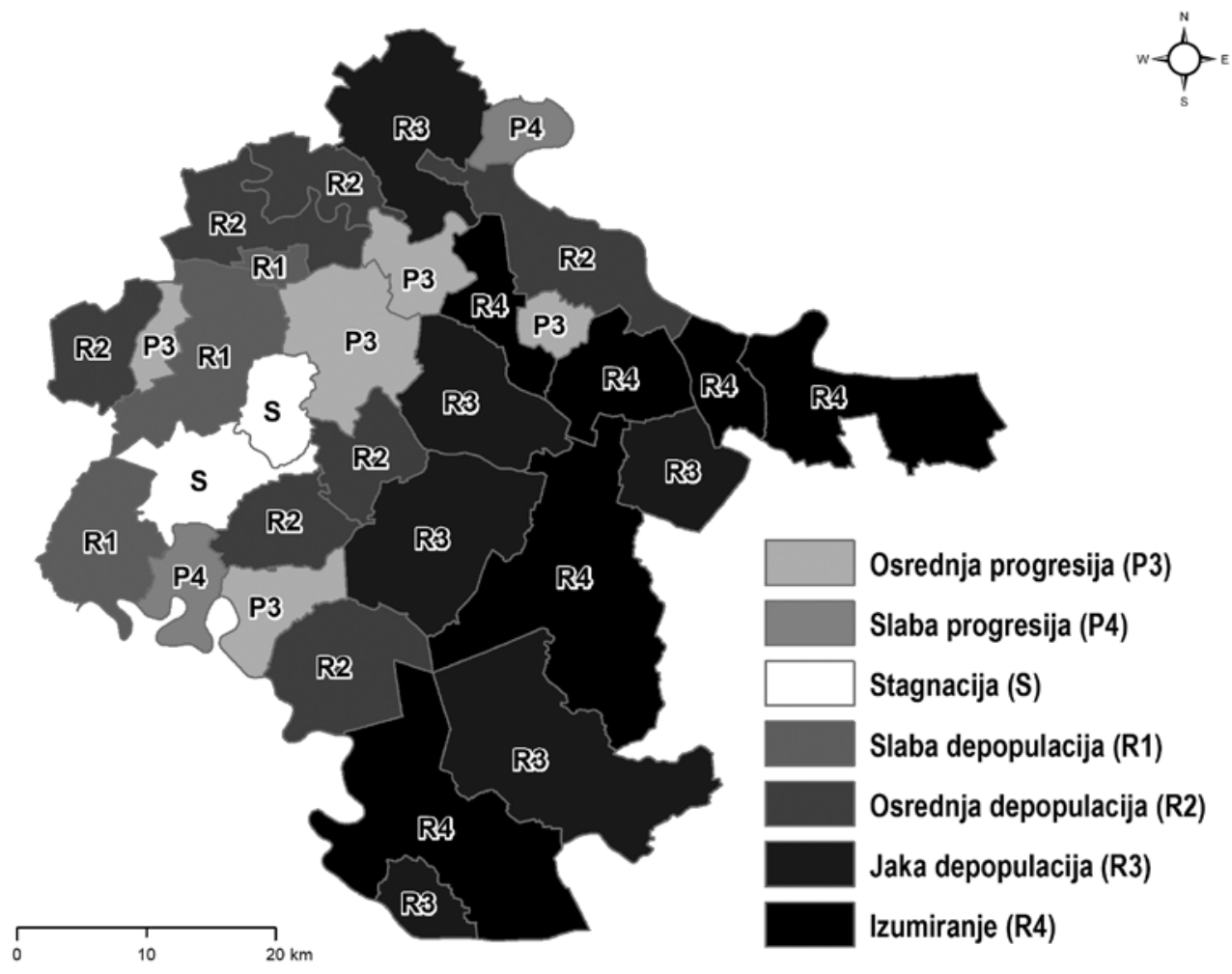

Kartogram 1. Tip intenziteta međupopisne promjene broja stanovnika Vukovarsko-srijemske županije po gradovima/općinama 2001. - 2017. godine

\subsection{Prirodno kretanje stanovništva 2001. - 2017. godine}

Prva dinamička sastavnica ukupnoga kretanja stanovništva jest bioreprodukcija, odnosno prirodna promjena koja je sumarni izraz dviju sastavnica prirodnoga kretanja - nataliteta ili rodnosti i mortaliteta ili smrtnosti stanovništva, pri čemu natalitet doprinosi aktivi, a mortalitet pasivi demografske bilance. Predznak odnosa između broja živorođene djece i umrlih stanovnika (ukupno kroz određeno razdoblje ili na godišnjoj razini), koji može biti pozitivan (prirodni prirast), negativan (prirodni pad ili prirodna depopulacija $\mathrm{u}$ tzv. zatvorenim populacijama) ili stagnantan, signifikantno utječe na veličinu i strukturu demografske bilance, odnosno determinira ukupno kretanje stanovništva pravcu njegova brojčanoga porasta ili u pravcu njegova brojčanoga pada ili ukupne depopulacije. 
Uvodno treba istaknuti da je bioreprodukcija stanovništva u općim uvjetima demografskoga razvoja funkcija strukturno-dinamičkih procesa, ali i vjerodostojan pokazatelj složene međuovisnosti demografskih, gospodarskih i društvenih procesa $u$ najširem smislu te riječi. ${ }^{34} \mathrm{U}$ normalnim je uvjetima koji nisu destabilizirani dugoročnim djelovanjem nepovoljnih endogenih i eksternih čimbenika, poput, primjerice ratova ili prirodnih katastrofa, prirodno kretanje stanovništva uglavnom pozitivna determinanta ukupnoga kretanja stanovništva i demografske bilance. No poremećaji u prirodnoj dinamici, neovisno o tome imaju li stihijski ili ubrzani (,akutni“) karakter, a mogu biti uzrokovani različitim endogenim i/ili eksternim čimbenicima demografskoga, društvenoga i gospodarskoga kompleksa, rezultirat će negativnim trendovima u drugim sastavnicama i dimenzijama kretanja i razvoja neke populacije. $\mathrm{I}$, vice versa, negativni demografski trendovi u domeni mehaničkoga i ukupnoga kretanja stanovništva te formiranja demografskih struktura, napose biološke (pojava i ubrzanje demografskoga starenja), nepovoljno će djelovati na bioreprodukciju, osobito na kretanje nataliteta, izazivajući njegovom brojčanom redukcijom nove remetilačke utjecaje, ponajprije u kontekstu oblikovanja vitalnih demografskih struktura kao što je, primjerice, biološka struktura stanovništva (dob, spol, bračno stanje). Negativna prirodna promjena $\mathrm{u}$ Vukovarsko-srijemskoj županiji statistički potvrđena kroz cijelo tematizirano razdoblje, prema svojemu je uzroku usko povezana uz izrazito nepovoljne i dugoročne posljedice Domovinskoga rata i duge okupacije, ${ }^{35}$ kako u domeni visokoga ratnoga mortaliteta, prisilnih migracija te nedovoljno brzoga i brojnijega povratka tako i u smislu snažne i duboke društvene i gospodarske krize koja je svom silinom zahvatila istok Hrvatske te u sinergiji s naslijeđenim sve lošijim demografskim procesima i trendovima izazvala njegovo posvemašnje populacijsko nazadovanje i pražnjenje. Duboka kriza u bioreprodukciji stanovništva Vukovarsko-srijemske županije, zahvaljujući ubrzanju nepovoljnih trendova $\mathrm{u}$ formiranju biološke strukture, kao i jačanju iseljavanja fertilnoga stanovništva u najboljoj reproduktivnoj dobi, počinje 1999. godine, od kada u toj županiji traje kontinuirana prirodna depopulacija, tj. na godišnjoj se razini više umire nego što se djece rađa, premda su uzročnici prirodnoga smanjenja još dublji i sežu unatrag stotinu pa i više godina (,bijela kuga“).

34 Detaljnije vidjeti u: Wertheimer-Baletić, Alica, 1999. Stanovništvo i razvoj, Zagreb: MaTe. Gospodarska misao.

Od ukupno 84 naselja u Vukovarsko-srijemskoj županiji tijekom ratne agresije bila su okupirana 54 naselja (64,3\% svih naselja Vukovarsko-srijemske županije), u koja su se prognanici u zamjetnijem broju počeli vraćati tek nakon 15. siječnja 1998. godine i formalnoga završetka procesa mirne reintegracije. Relativan udio povratnika u odnosu na registrirani broj prognanika kretao se u rasponu od 57,1\% u Gradu Vukovaru do čak 94,6\% u Općini Nuštar (usp. Živić, Turk, 2011.). 
Brojčani pokazatelji prirodne depopulacije stanovništva Vukovarsko-srijemske županije više su nego jasni i indikativni. Naime, 2001. - 2017. godine ukupno je u Vukovarsko-srijemskoj županiji živorođeno 30.491 dijete (godišnji je prosjek 1.794 živorođenih), a umrla je ukupno 38.901 osoba (godišnji je prosjek umrlih 2.288), pa je utvrđeno prirodno smanjenje od -8.410 stanovnika (godišnji prosjek prirodnoga pada iznosio je -135 stanovnika). Prosječna je stopa nataliteta iznosila $9,9 \%$, mortaliteta $12,8 \%$, a prirodne promjene $-2,8 \%$ o. Na godišnjoj je razini stopa nataliteta pala ispod $10 \%$ o 2011., a u kontinuitetu je ispod te razine od 2013. godine, što ukazuje na činjenicu da je Vukovarsko-srijemska županija poprimila dugoročno postojana nepovoljna niskonatalitetna obilježja bioreprodukcije, što svakako ide u prilog ocjeni da je prirodno kretanje stanovništva te županije negativna odrednica njezine demografske bilance i ukupnoga kretanja stanovništva. Ujedno, izračunati vitalni indeks snažno upozorava na opadajuću bioreprodukciju stanovništva. U svim je analiziranim godinama njegova vrijednost ispod 100, što je granica između populacije s opadajućom i populacije s proširenom bioreprodukcijom. Najniža vrijednost vitalnoga indeksa na godišnjoj razini zabilježena je 2017. (55,1), dok je prosječna vrijednost vitalnoga indeksa kroz cijelo promatrano razdoblje iznosila 78,6, pa se može konstatirati da je u prosjeku natalitet uspio nadomjestiti manje od $80 \%$ prirodnoga gubitka determiniranoga apsolutnom razinom smrtnosti stanovništva. Pritom svakako treba upozoriti da je od 2015. godine vitalni indeks ispod vrijednosti 60 (u posljednje tri godine iznosio je u prosjeku svega 59,1), što nas ubrzano približava odnosu u kojemu će broj umrlih u Županiji dvostruko nadmašiti broj živorođene djece. U tomu brojčanomu okviru bioreprodukcije teško možemo očekivati demografsku revitalizaciju Županije vlastitim demoreproduktivnim potencijalima. To više kada $u$ analizu uvrstimo i odabrane pokazatelje promjene biološke strukture stanovništva između popisa 2001. i 2011., odnosno procjene za 2017. godinu (tablica 3) zahvaljujući kojima se ne zrcali samo prošlost nego odražava i demografska budućnost te županije. ${ }^{36}$

\footnotetext{
36 Detaljnije o polustoljetnim promjenama u strukturi stanovništva Vukovarsko-srijemske županije po dobi i spolu vidjeti u: Pejaković, 2016. Autor, među ostalim iznesenim i interpretiranim činjenicama i dokumentiranim zaključcima, navodi da se prema stupnju (tipu) ostarjelosti Vukovarsko-srijemske županije 1961. nalazila na pragu starenja, a 2011. godine u dubokoj starosti, uz napomenu da ova županija, zbog dugoga imigracijskoga karaktera u formiranju naseljenosti, u odnosu na hrvatski prosjek ima nešto povoljnija (,mlađa“) obilježja biološke strukture stanovništva.
} 
U tom smislu osobito zabrinjavaju sljedeći pokazatelji: ${ }^{37}$

1. Broj stanovnika do 14. godine starosti (mlado stanovništvo) smanjen je u samo jednom desetljeću (2001. - 2011.) za 22,6\%, broj stanovnika 15. - 64. godine starosti (zrelo stanovništvo) smanjen je u istomu međupopisju za 12,2\%, a broj stanovnika starijih od 65 . godine života (staro stanovništvo) povećan je za zamjetnih 3,8\%. Stoga ne začuđuje da su osnovni indikatori dobne strukture, u odnosu na razdoblje do 2001. godine, dodatno pogoršani: koeficijent mladosti smanjen je s 19,2\% na $17,0 \%$, koeficijent starosti povećan je s $14,4 \%$ na $17,1 \%$, dok je indeks starenja povećan sa 75,1 na 100,8, što znači da je 2011. godine stanovništvo starije od 65. godine života svojim brojem i relativnim udjelom u ukupnomu stanovništvu postalo izjednačeno s velikom dobnom skupinom mladoga stanovništva (do 14. godine). Odraz je to sve lošijih trendova u bioreprodukciji i migracijama. Nizak natalitet generira smanjenje priljeva stanovništva u mladu i zrelu dob, dok produljenje ljudskoga vijeka i pristizanje brojnih naraštaja rođenih u kompenzacijskomu razdoblju povećanoga nataliteta nakon Drugoga svjetskoga rata u staru dob determinira povećanje obujma i relativnoga udjela starih dobnih kohorti. S obzirom na diferencirano kretanje broja stanovnika prema velikim dobnim skupinama razvidno je da se u Vukovarsko-srijemskoj županiji proces demografskoga starenja odvija primarno kao „starenje odozdo", čiji je osnovni i najvažniji čimbenik pad nataliteta/fertiliteta.

2. Procjena DZSRH za 2017. godinu (tablica 3) pokazuje da se proces demografskoga starenja nastavlja, pače da on progredira u broju kao i strukturi stanovništva po dobi i nakon posljednjega popisa stanovništva. Naime, od popisa 2011. do sredine 2017. godine broj mladih smanjen je za novih 20,1\%, pa oni, prema procjeni za 2017. godinu, čine svega $15,3 \%$ ukupnoga stanovništva Vukovarsko-srijemske županije. Riječ je o stanovništvu u pretfertilnoj dobi koje bi, kada uđe u fertilno razdoblje života, trebalo nositi nupcijalitet i demoreprodukciju, tj. biti osloncem demografske održivosti stanovništva Županije u nadolaze-

\footnotetext{
Na ovomu je mjestu potrebno upozoriti na činjenicu da je u oba popisa struktura stanovništva po spolu i dobi dana samo za ukupan broj stanovnika, što znači da ona 2001. godine uključuje i dobnospolni sastav stanovništva Hrvatske popisanih u inozemstvu, a ne samo "u zemlji“, kao što je to u popisu 2011. godine. To znači da postoji bitno smanjena razina međupopisne usporedivosti biološke strukture između dva posljednja popisa stanovništva. No trend nije upitan i podatci premda smanjene usporedivosti jasno indiciraju jačanje disbalansa u odnosu među velikim dobnim skupinama kao i trend ubrzanja demografskoga starenja.
} 
ćem razdoblju. No pitanje je hoće li to ono moći u uvjetima jake demografske regresije koju dokumentiraju i popisni rezultati i relevantne procjene, odnosno u kontekstu drugih društvenih i ekonomskih trendova i procesa s druge strane, koji na reproduktivno ponašanje i norme imaju sve veći negativan učinak. Tu se, prije svega, misli na gospodarsku i društvenu, ali i identitetsku i vrijednosnu krizu koje ne pridonose stvaranju pozitivnoga društvenoga ozračja prema braku, obitelji i napose odluci o imanju djece. Ujedno, broj zreloga stanovništva također depopulira, i to za novih $12,1 \%$, pa relativan udio stanovništva 15. - 64 . godine života iznosi $65,3 \%$. Procjene također pokazuju da je broj staroga stanovništva sredinom 2017. u odnosu na popis 2011. godine opet blago povećan (za 0,5\%), ali njegov demografski porast treba promatrati u kontekstu nastavka ukupne depopulacije Vukovarsko-srijemske županije, koja je od popisa 2011. do sredine 2017. godine (procjena) dosegnula $-11,3 \%$. Relativan udio staroga u ukupnomu stanovništvu Vukovarsko-srijemske županije gotovo je dosegnuo petinu ukupne populacije Županije, a indeks starenja od 126,8 kazuje da je procijenjeni broj starih za četvrtinu veći od procijenjenoga broja mladih. Imajući u vidu suvremene trendove $u$ bioreprodukciji, osobito redukciju nataliteta $i$ jačanje disbalansa među velikim (funkcionalnim) dobnim skupinama, novo ubrzanje procesa demografskoga starenja više je nego izvjesno u razdobljima koja dolaze. To više što je dio poremećenih („okrnjenih“) odnosa u piramidi starosti Vukovarsko-srijemske županije uzrokovan iseljavanjem stanovništva u najpovoljnijoj reproduktivnoj i radnosposobnoj dobi života (20. - 40. godine).

Tablica 2. Prirodno kretanje stanovništva Vukovarsko-srijemske županije 2001. - 2017. godine

\begin{tabular}{|c|c|c|c|c|c|c|c|}
\hline Godina & $\begin{array}{c}\text { Broj djece } \\
\text { živorođene }\end{array}$ & $\begin{array}{c}\text { Broj } \\
\text { umrlih } \\
\text { stanovnika }\end{array}$ & $\begin{array}{c}\text { Prirodna } \\
\text { promjena }\end{array}$ & $\begin{array}{c}\text { Vitalni } \\
\text { indeks }\end{array}$ & $\begin{array}{c}\text { Stopa } \\
\text { nataliteta }\end{array}$ & $\begin{array}{c}\text { Stopa } \\
\text { mortaliteta }\end{array}$ & $\begin{array}{c}\text { Stopa } \\
\text { prirodne } \\
\text { promjene }\end{array}$ \\
\hline 2001. & 2084 & 2136 & -52 & 97,6 & 10,9 & 11,2 & $-0,3$ \\
\hline 2002. & 1946 & 2250 & -304 & 86,5 & 10,3 & 11,9 & $-1,6$ \\
\hline 2003. & 1901 & 2249 & -348 & 84,5 & 10,1 & 11,9 & $-1,8$ \\
\hline
\end{tabular}


Rad Hrvat. akad. znan. i umjet. Razred za druš. znan. 54=539(2019) : 163-203

Dražen Živić: Migracijska komponenta ukupnoga kretanja stanovništva Vukovarsko-srijemske županije 2001. - 2017.

\begin{tabular}{|c|c|c|c|c|c|c|c|}
\hline 2004. & 1971 & 2180 & -209 & 90,4 & 10,5 & 11,7 & $-1,1$ \\
\hline 2005. & 2052 & 2333 & -281 & 88,0 & 11,0 & 12,5 & $-1,5$ \\
\hline 2006. & 1950 & 2242 & -292 & 87,0 & 10,5 & 12,1 & $-1,6$ \\
\hline 2007. & 1942 & 2293 & -351 & 84,7 & 10,5 & 12,4 & $-1,9$ \\
\hline 2008. & 1994 & 2340 & -346 & 85,2 & 10,8 & 12,7 & $-1,9$ \\
\hline 2009. & 1948 & 2350 & -402 & 82,9 & 10,6 & 12,8 & $-2,2$ \\
\hline 2010. & 1813 & 2334 & -521 & 77,7 & 10,0 & 12,9 & $-2,9$ \\
\hline 2011. & 1698 & 2269 & -571 & 74,8 & 9,5 & 12,7 & $-3,2$ \\
\hline 2012. & 1772 & 2325 & -553 & 76,2 & 10,0 & 13,1 & $-3,1$ \\
\hline 2013. & 1593 & 2261 & -668 & 70,5 & 9,1 & 12,9 & $-3,8$ \\
\hline 2014. & 1651 & 2270 & -619 & 72,7 & 9,5 & 13,1 & $-3,6$ \\
\hline 2015. & 1438 & 2400 & -962 & 59,9 & 8,5 & 14,2 & $-5,7$ \\
\hline 2016. & 1436 & 2307 & -871 & 62,2 & 8,7 & 13,9 & $-5,3$ \\
\hline 2017. & 1302 & 2362 & -1060 & 55,1 & 8,2 & 14,8 & $-6,7$ \\
\hline $\begin{array}{c}2001 .- \\
2010 .\end{array}$ & 19601 & 22707 & -3106 & 86,5 & 10,5 & 12,2 & $-1,7$ \\
\hline $\begin{array}{c}2011 .- \\
2017 .\end{array}$ & 10890 & 16194 & -5304 & 67,3 & 9,1 & 13,5 & $-4,5$ \\
\hline $\begin{array}{c}2001 .- \\
2017 .\end{array}$ & 30491 & 38901 & -84510 & 78,6 & 9,9 & 12,8 & $-2,8$ \\
\hline
\end{tabular}

IZVOR: Publikacije prema statističkim područjima, Stanovništvo, Prirodno kretanje

stanovništva Republike Hrvatske, 7.1.1. Priopćenja o prirodnom kretanju stanovništva, DZSRH, Zagreb (www.dzs.hr; pristupljeno 28. veljače 2019.); Publikacije prema statističkim područjima, Stanovništvo, 7.1.3. Procjene stanovništva Republike Hrvatske, DZSRH, Zagreb (www.dzs.hr; pristupljeno 25. veljače 2019.). 
Tablica 3. Odabrani indikatori strukture stanovništva Vukovarsko-srijemske županije po dobi i spolu prema rezultatima popisa 2001. i 2011. te procjeni za 2017. godinu.

\begin{tabular}{|c|c|c|c|}
\hline Indikatori & 2001. & 2011. & 2017. (procjena) \\
\hline Ukupan broj stanovnika & 204768 & 179521 & 159213 \\
\hline Muškarci & 98470 & 86682 & 76965 \\
\hline Žene & 106298 & 92839 & 82248 \\
\hline Koeficijent maskuliniteta & 92,6 & 93,4 & 93,6 \\
\hline Koeficijent feminiteta & 107,9 & 107,1 & 106,9 \\
\hline Broj stanovnika do 14 . godine & 39359 & 30451 & 24329 \\
\hline Broj stanovnika od 15 . do 64 . godine & 134860 & 118382 & 104045 \\
\hline Broj stanovnika 65 godina i stariji & 29576 & 30688 & 30839 \\
\hline Koeficijent mladosti & 19,2 & 17,0 & 15,3 \\
\hline Koeficijent starosti & 14,4 & 17,1 & 19,4 \\
\hline Indeks starenja & 75,1 & 100,8 & 126,8 \\
\hline Prosječna starost & 37,8 & 40,6 & 42,5 \\
\hline Prosječna starost $\mathrm{RH}$ & 39,3 & 41,7 & 43,1 \\
\hline
\end{tabular}

Izvori: Popisi stanovništva 2001. i 2011., DZSRH, Zagreb (www.dzs.hr; pristupljeno 20. veljače 2019.); Publikacije prema statističkim područjima, Stanovništvo, 7.1.3. Procjene stanovništva Republike Hrvatske u 2017., DZSRH, Zagreb (www.dzs.hr; pristupljeno 25. veljače 2019.). 


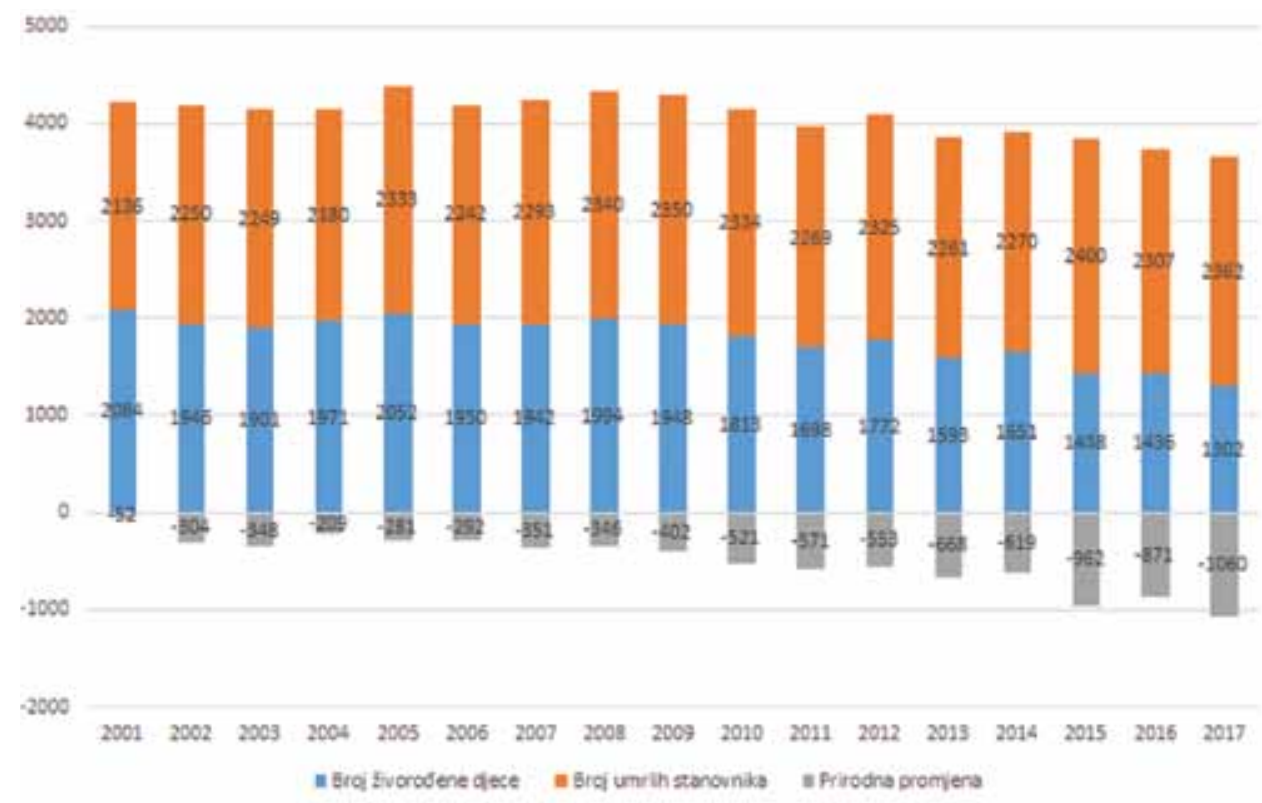

Grafikon 1. Apsolutne vrijednosti prirodnoga kretanja stanovništva Vukovarsko-srijemske županije 2001.-2017. godine

\subsection{Mehaničko kretanje stanovništva 2001. - 2017.}

Mehaničko kretanje stanovništva ili migracije, uz bioreprodukciju (natalitet i mortalitet), druga su dinamička odrednica i sastavnica ukupnoga kretanja stanovništva, s tim da imigracija determinira aktivu, a emigracija pasivu demografske bilance. Razlika između broja doseljenih (imigranata) i odseljenih (emigranata) čini migracijsku bilancu ili saldo ukupne migracije. Ovisno o predznaku salda ukupne migracije, tj. o tome prevladava li u strukturi migranata doseljeno ili odseljeno stanovništvo, migracije utječu na porast, stagnaciju ili pad broja stanovnika na nekomu području, odnosno determiniraju demografsku bilancu u pozitivnom ili negativnom kontekstu. $\mathrm{Na}$ demografski, društveni i ekonomski razvoj određenoga prostora migracija djeluje putem broja migranata (doseljenika ili odseljenika), njihovih struktura (spol, dob, obrazovanje, bračni i obiteljski status, ekonomska aktivnost, zanimanje, religijska i etnička struktura i sl.) kao i smjera prostorne pokretljivosti (unutarnja i vanjska migracija). Migracije, uobičajeno se drži, imaju 
kratkoročne, ali i - što je osobito važno - dugoročne ili odgođene učinke, kako $\mathrm{u}$ ishodišnim tako i u odredišnim područjima migracijskih struja. ${ }^{38}$

Znanstvenim je istraživanjima već utvrđeno da je današnja Vukovarskosrijemska županija tijekom proteklih stoljeća bila „otvoreno migracijsko područje", u kojemu su se, sukladno društveno-političkim, povijesnim, demografskim, vojnim i drugim procesima i administrativno-teritorijalnim promjenama, smjenjivala razdoblja (desetljeća) povećanoga doseljavanja novoga stanovništva s periodima brojnijega odseljavanja domicilne populacije. Samo u 20. stoljeću bilo je nekoliko značajnijih migracijskih valova koji su umnogome promijenili, a dokumentirano se može tvrditi i pogoršali, demografska i druga obilježja naseljenosti Vukovarsko-srijemske županije kako u smislu slabljenja stope porasta broja stanovnika tako i u smislu velikih strukturnodemografskih promjena. Među ostalim, riječ je o migracijskim strujama povezanima uz: (1) Prvi i Drugi svjetski rat i njihove složene društvene, političke, ekonomske i druge posljedice koje su u brojčanom smislu imale vrlo značajne demografske i migracijske posljedice (npr. egzodus Mađara i Nijemaca nakon Prvoga i protjerivanje Nijemaca nakon Drugoga svjetskoga rata); ${ }^{39}$ (2) uz agrarno-kolonizacijske migracijske struje u sklopu triju agrarnih reformi; prve nakon 1918. i u međuratnomu periodu (1918. - 1940.), druge koju je provodila NDH u vrijeme Drugoga svjetskoga rata te treće nakon Drugoga svjetskoga rata i u poraću (1945. - 1948.); (3) uz procese deagrarizacije i deruralizacije, čije su posljedice, zbog njihove spontanosti i nedovoljne osmišljenosti razvoja nepoljoprivrednih gospodarskih djelatnosti, tj. nedovoljne ponude radnih mjesta $\mathrm{u}$ sekundarnomu i tercijarnomu sektoru, $\mathrm{u}$ migracijskomu kontekstu ponajviše izražene u egzodusu ruralnoga stanovništva 1960-ih i 1970-ih godina (prema velikim hrvatskim gradovima te $u$ inozemstvo); (4) uz Domovinski rat 1990-ih godina i prisilno iseljavanje nesrpskoga stanovništva s okupiranih dijelova Županije te diferenciranoga i necjelovitoga povratka prognanika, izbjeglica i raseljenih osoba nakon okončanja rata, osobito po završetku mirne reintegracije u siječnju 1998. godine; kao i (5) uz jačanje novoga iseljeničkoga vala u posljednjih desetak godina zbog ekonomske i socijalne krize te nedostatka jasnije vizije razvoja hrvatskoga gospodarstva i uklanjanja/ublažavanja prostorne (regionalne) razvojne neravnoteže.

$\overline{38}$ Detaljnije o fenomenu migracija, njezinim odrednicama, oblicima i tipologiji, kao i širim demografskim, društvenim i gospodarskim implikacijama vidjeti u: Wertheimer-Baletić, 1999.

39 O demografskim prilikama i promjenama na području današnje Vukovarsko-srijemske županije iz perspektive Prvoga i Drugoga svjetskoga rata detaljnije vidjeti u: Karaman, Igor (ur.). 1994. Vukovar - vjekovni hrvatski grad na Dunavu, Koprivnica: Naklada dr. Feletar; Wertheimer-Baletić, 1993.b.; Živić, 2006. 
Pritom treba istaknuti da migracijska obilježja Vukovarsko-srijemske županije, neovisno o vremenskom rasponu i strukturnim karakteristikama i predznaku mehaničkoga kretanja stanovništva, treba promatrati u kontekstu širih migracijsko-demografskih procesa i trendova na hrvatskom istoku. Stoga je i suvremena migracija u Županiji kontekstualno razumljiva jedino ako je se stavi u okvir koji definiraju sve nepovoljniji migracijski, demografski, društveni i ekonomski trendovi i procesi karakteristični za cijeli hrvatski istok, ${ }^{40}$ odnosno za cijelu Republiku Hrvatsku. ${ }^{41}$ Naime, masovno iseljavanje pouzdan je indikator društveno-gospodarskoga zaostajanja u odnosu na odredišta suvremenih iseljeničkih struja, neovisno o tome je li riječ o unutarnjoj ili vanjskoj migraciji. Sve izraženije razvojne "napetosti“ bitan su push faktor iseljavanja, što Vukovarsko-srijemsku županiju, kao i druge istočnohrvatske županije, sve više pozicionira kao „hrvatsku demografsku periferiju“. Dakako, suvremena migracija u Vukovarsko-srijemskoj županiji ima i neke svoje specifičnosti koje se ponajprije ogledaju u činjenici da je riječ o županiji čija su dinamička i strukturna demografska obilježja sve nepovoljnija i u kojoj će brojčano veliki migracijski gubitci (tj. negativni saldo ukupne migracije), dugoročno gledano, imati vrlo nepovoljne posljedice na ionako već poremećene demografske odnose, napose kada imamo u vidu granični karakter Županije (prema Srbiji te Bosni i Hercegovini) i predvidljiv nastavak njezina demografskoga pražnjenja. ${ }^{42}$

Analizu veličine i strukture migracijske komponente u ukupnomu kretanju stanovništva Vukovarsko-srijemske županije, kao što je u metodološkim napomenama već naznačeno, izvršili smo na dva načina: (1) komparativnom vitalnostatističkom metodom stavljajući $u$ odnos međupopisnu promjenu prisutnoga broja stanovnika (,u zemlji“) na osnovi rezultata popisa 2001. i 2011. godine i prirodnu promjenu (razliku između broja živorođene djece i umrlih stanovnika), korigirajući je za prvu i posljednju godinu u tomu međupopisnomu razdoblju zbog usklađivanja prirodne dinamike stanovništva s kritičnim vremenskim trenutkom popisa (31. ožujka / 1. travn-

$\overline{40}$ Detaljnije vidjeti u: Živić, Dražen, 2016. Suvremena migracija kao odrednica depopulacije istočne Hrvatske, u: Zbornik radova Sociokulturno nasljeđe i gospodarski razvoj (Šundalić, Antun, Zmaić, Krunoslav, Sudarić, Tihana, Pavić, Željko, ur.), Osijek: Sveučilište J. J. Strossmayera u Osijeku, Poljoprivredni fakultet, Odjel za kulturologiju, Ekonomski fakultet, 52-75.

41 Usp. Klempić Bogadi, Lajić, 2014; Nejašmić, 2014.

42 Usp. Živić, Dražen, Turk, Ivo, Šimunić, Nikola, 2017. Demografske promjene u Vukovarskosrijemskoj županiji (2001. - 2014.) u zrcalu nacionalne sigurnosti, u: Domovinska (i europska) sigurnost. Kriza sigurnosti i politike manipuliranja suverenitetom (Cvikić, Sandra, Žebec Šilj, Ivana, Bendra, Ivana, ur.), Zagreb - Vukovar: Institut društvenih znanosti Ivo Pilar, 39-72. 
ja); (2) izračunom salda ukupne, unutarnje i vanjske migracije stanovništva Vukovarsko-srijemske županije za razdoblje 2001. - 2017. godine na temelju godišnjih priopćenja o migraciji u Republici Hrvatskoj koje objavljuje DZSRH, vodeći pritom, kako je već istaknuto, računa o necjelovitosti, a time i nedovoljne pouzdanosti službenih podataka vanjske migracije stanovništva Hrvatske.

1. Procjena grube migracijske bilance stanovništva Vukovarsko-srijemske županije 2001. - 2011.

Prema kriteriju prisutnosti (stanovništva „,u zemlji“), broj stanovnika u Vukovarsko-srijemskoj županiji smanjen je u međupopisju 2001. - 2011. godine sa 186.185 na 179.521 , što znači da je apsolutni pad iznosio -6.664 osobe, a relativno smanjenje $-3,6 \%{ }^{43} \mathrm{U}$ istomu je razdoblju prirodna promjena također bila negativna i iznosila je -3.236 stanovnika (19.505 živorođenih i 22.739 umrlih), što je $\mathrm{u}$ relativnom smislu $-1,7 \% \mathrm{u}$ odnosu na broj prisutnoga stanovništva 2001. godine. To znači da je i gruba migracijska bilanca kao procijenjena razlika između broja doseljenih i odseljenih osoba bila negativnoga predznaka (-3.428 stanovnika ili -1,8\% u odnosu na prisutno stanovništvo 2001.), a da je tip općega kretanja stanovništva bio najlošiji - trend izumiranja. ${ }^{44}$ Navedeno implicira zaključak da je u strukturi ukupnoga kretanja stanovništva Vukovarskosrijemske županije u posljednjemu međupopisnomu razdoblju 2001. - 2011. godine, na temelju vitalnostatističke metode procjene, prirodni pad stanovništva Županije sudjelovao s $48,6 \%$, a procijenjena negativna migracijska bilanca Županije s $51,4 \%$. Dakle, u posljednjemu međupopisju migracijska komponenta u ukupnomu kretanju stanovništva Vukovarsko-srijemske županije u odnosu na bioreprodukciju u blagoj je prednosti. No izvjesno je, na temelju (nepotpunih) podataka migracijske statistike, da će uloga mehaničkoga u ukupnomu kretanju stanovništva Županije još uvijek neko vrijeme rasti. To je već vidljivo u procjeni demografske bilance Županije za razdoblje 2011. - 2017. godine.

\footnotetext{
43 Komparativnom vitalnostatističkom metodom utvrđena je negativna gruba migracijska bilanca za stanovništvo „u zemlji“ i u svim međupopisnim razdobljima od 1971. do 2001. godine. Usp. Wertheimer-Baletić, Akrap, 2008.

44 Prema tipologiji općega kretanja stanovništva (,u zemlji“), za razdoblje 2001. - 2011. godine, većina gradova i općina Vukovarsko-srijemske županije ima najnepovoljniji trend izumiranja (gradovi Ilok, Otok i Vukovar) te općine: Bogdanovci, Bošnjaci, Drenovci, Gradište, Gunja, Lovas, Nijemci, Privlaka, Stari Jankovci, Stari Mikanovci, Tompojevci, Tordinci, Tovarnik, Trpinja i Vrbanja. Izrazitu depopulaciju kao egzodusni trend općega kretanja stanovništva imala je Općina Babina Greda, trend depopulaciju općine Ivankovo i Jarmina te trend emigraciju općine Andrijaševci, Cerna i Vođinci. Jedino su gradovi Vinkovci i Županja te općine: Borovo, Markušica Negoslavci, Nuštar i Štitar imali povoljnije imigracijske tipove općega kretanja stanovništva (Živić, Turk, Šimunić, 2017., str. 54).
} 
2. Saldo ukupne, unutarnje i vanjske migracije stanovništva Vukovarskosrijemske županije 2001. - 2017.

Prema podatcima DZSRH, uz opetovani oprez pri njihovoj interpretaciji, utvrđeno je da se u razdoblju 2001. - 2017. godine u Vukovarsko-srijemsku županiju doselila (prijavila prebivalište) ukupno 24.421 osoba, ${ }^{45}$ od kojih je 15.530 osoba ili 63,6\% doseljeno iz drugih hrvatskih županija, dok se 8.891 osoba ili $36,4 \%$ doselila iz inozemstva (tablica 4). U istomu se razdoblju iz Županije odselio (odjavio prebivalište) ukupno 49.771 stanovnik, ${ }^{46}$ od kojih su se 30.084 osobe ili $60,4 \%$ odselile u druge hrvatske županije, a 19.597 stanovnika ili $39,6 \%$ u inozemstvo (tablica 5). Stopa emigracije iznosila je 103,8, a stopa imigracije 49,1, što znači da je kroz promatrano razdoblje broj iseljenih iz Županije bio dvostruko veći od broja doseljenih u nju. Iz navedenih podataka proizlazi da su oba migracijska salda bila negativna: saldo unutarnje migracije iznosio je -14.554 stanovnika, a saldo vanjske migracije -10.706 stanovnika, što znači da je Vukovarsko-srijemska županija $u$ analiziranomu razdoblju gubila stanovništvo ne samo negativnom (opadajućom) bioreprodukcijom nego i mehaničkim putem, tj. brojnim iseljavanjem $u$ druge hrvatske županije i inozemstvo od doseljavanja iz drugih hrvatskih županija i inozemstva. Potonje dobro dokumentira i vrijednost salda ukupne migracije kao i kretanje opće stope neto migracije (tablica 6). Naime, ne računajući unutaržupanijsku prostornu pokretljivost stanovništva, Vukovarsko-srijemska županija u razdoblju 2001. - 2017. godine zabilježila je negativan saldo ukupne migracije od -25.350 stanovnika, tj. tolika je razlika između ukupnoga broja doseljenih (prijavljeno prebivalište) u županiju i broja iseljenih iz nje (odjavljeno prebivalište). Prosječna opća stopa neto migracije iznosila je zamjetnih $-8,7 \%$. Kretanje salda ukupne migracije, a - sukladno tomu - $\mathrm{i}$ opće stope neto migracije, kroz promatrano je razdoblje kontinuirano bilo negativno, s tim da se zbog vremenske diferenciranosti intenziteta migracijskoga gubitka mogu izdvojiti dva uža razdoblja emigracijske depopulacije: (1) između 2001. i 2008. godine, tijekom kojega je negativan saldo ukupne migracije iznosio -4.732 (18,7\% ukupnoga negativnoga salda migracije), a prosječna opća stopa neto migracije -3,2\%; (2) između 2009. i 2017. godine, tijekom kojega je negativan saldo ukupne migracije iznosio -20.628 (81,3\% ukupnoga negativnoga salda migracije), a prosječna opća stopa neto migracije iznosila čak $-13,6 \%$. Osobito zabrinjavaju posljednje četiri godine (2014. - 2017.) u uspostavljenoj vremenskoj seriji

\footnotetext{
45 Navedena brojka ne uključuje unutaržupanijske migracije između gradova/općina iste županije, odnosno između naselja istoga grada/općine Vukovarsko-srijemske županije.

46 Navedena brojka ne uključuje unutaržupanijske migracije između gradova/općina iste županije, odnosno između naselja istoga grada/općine Vukovarsko-srijemske županije.
} 
podataka migracijske statistike jer je $\mathrm{u}$ tomu razdoblju negativan saldo ukupne migracije dosegnuo -14.482 osobe ili značajno više od polovice $(57,1 \%)$ ukupnoga negativnoga salda migracije Vukovarsko-srijemske županije kroz cijelo razdoblje 2001. - 2017. godine. Prosječna opća stopa neto migracije u posljednje četiri godine analiziranoga razdoblja iznosila je iznimno visokih $-22,0 \%$.

Potonji izračun salda ukupne migracije stanovništva ukazuje da važnost migracijske komponente u ukupnomu kretanju stanovništva Vukovarsko-srijemske županije raste. ${ }^{47}$ Promjena vrijednosti opće stope neto migracije na razini gradova/općina Vukovarsko-srijemske županije (tablica 7) potvrđuje tu ocjenu. Komparirajući opću stopu neto migracije za 2011. i 2017. godinu neprijeporno je da u Županiji postoji izrazito visok stupanj homogenosti negativnoga migracijskoga salda, ali se uočava i sve intenzivniji gubitak stanovništva mehaničkim putem. Tako je, primjerice, 2011. negativnu opću stopu neto migracije imalo 28 , a 2017. godine čak 30 od ukupno 31 jedinice lokalne samouprave Vukovarskosrijemske županije. Izuzetak su s pozitivnom općom stopom neto migracije 2011. bile općine Bogdanovci (1,0\%), Borovo (2,6\%) i Negoslavci (6,2\%), dok je 2017. godine „pozitivna“ bila samo Općina Nuštar (4,6\%). Raspon negativnih općih stopa neto migracije 2011. kretao se od -0,4\% (Andrijaševci) do -30,7\% (Štitar), a 2017. godine od $-15,8 \%$ (Vinkovci) do $-92,1 \%$ (Štitar). Dakle, najmanja negativna vrijednost opće stope neto migracije povećana je $\mathrm{s}-0,4 \%$ na $-15,8 \%$, a najviša $\mathrm{s}$ $-30,7 \%$ na $-92,1 \%$.

\footnotetext{
Držimo važnim na ovomu mjestu istaknuti razliku između apsolutne vrijednosti negativne migracijske bilance Vukovarsko-srijemske županije procijenjene vitalnostatističkom metodom (-3.428) i negativnoga salda ukupne migracije na temelju godišnjih priopćenja DZSRH (-7.374) u razdoblju 2001. - 2011. godine. Teško je bez detaljnijih analitičkih uvida cjelovito obrazložiti razloge tomu, no moguće preliminarno objašnjenje moglo bi ležati u nejednakoj metodologiji popisa, tj. u činjenici da je zbog primjene kriterija ",namjere prisutnosti“ ukupan broj stanovnika Vukovarsko-srijemske županije u popisu 2011. godine bio veći od stvarnoga broja prisutnoga stanovništva.
} 
Tablica 4. Struktura doseljenoga stanovništva u Vukovarsko-srijemsku županiju 2001. - 2017. godine

\begin{tabular}{|c|c|c|c|c|c|}
\hline Godina & Ukupno* & $\begin{array}{c}\text { Doseljeni iz drugih } \\
\text { hrvatskih županija (A) }\end{array}$ & $\begin{array}{c}\text { Doseljeni iz } \\
\text { inozemstva (B) }\end{array}$ & $\begin{array}{l}\% \\
\mathrm{~A}\end{array}$ & $\begin{array}{l}\% \\
\mathrm{~B}\end{array}$ \\
\hline 2001. & 2277 & 1233 & 1044 & 54,2 & 45,8 \\
\hline 2002. & 1903 & 1283 & 620 & 67,4 & 32,6 \\
\hline 2003. & 1712 & 1094 & 618 & 63,9 & 36,1 \\
\hline 2004. & 1520 & 1002 & 518 & 65,9 & 34,1 \\
\hline 2005. & 1528 & 938 & 590 & 61,4 & 38,6 \\
\hline 2006. & 1677 & 1063 & 614 & 63,4 & 36,6 \\
\hline 2007. & 2121 & 1267 & 854 & 59,7 & 40,3 \\
\hline 2008. & 1749 & 986 & 763 & 56,4 & 43,6 \\
\hline 2009. & 1274 & 845 & 429 & 66,3 & 33,7 \\
\hline 2010. & 946 & 756 & 190 & 79,9 & 20,1 \\
\hline 2011. & 1037 & 726 & 311 & 70,0 & 30,0 \\
\hline 2012. & 1087 & 734 & 353 & 67,5 & 32,5 \\
\hline 2013. & 1076 & 751 & 325 & 69,8 & 30,2 \\
\hline 2014. & 1043 & 756 & 287 & 72,5 & 27,5 \\
\hline 2015. & 1165 & 731 & 434 & 62,7 & 37,3 \\
\hline 2016. & 1150 & 656 & 494 & 57,0 & 43,0 \\
\hline 2017. & 1156 & 709 & 447 & 61,3 & 38,7 \\
\hline Ukupno & 24421 & 15530 & 8891 & 63,6 & 36,4 \\
\hline
\end{tabular}

* Ne uključuje unutaržupanijske migracije.

IZVOR: Publikacije prema statističkim područjima, Stanovništvo, Migracije stanovništva Republike Hrvatske, 7.1.2. Priopćenja o migraciji stanovništva, DZSRH, Zagreb (www.dzs.hr; pristupljeno 15. siječnja 2019.). 
Tablica 5. Struktura odseljenoga stanovništva iz Vukovarsko-srijemske županije 2001. - 2017. godine

\begin{tabular}{|c|c|c|c|c|c|}
\hline Godina & Ukupno* & $\begin{array}{c}\text { Odseljeni u druge } \\
\text { hrvatske županije (A) }\end{array}$ & $\begin{array}{c}\text { Odseljeni u } \\
\text { inozemstvo (B) }\end{array}$ & $\begin{array}{l}\% \\
\mathrm{~A}\end{array}$ & $\begin{array}{l}\% \\
\mathrm{~B}\end{array}$ \\
\hline 2001. & 2558 & 1928 & 630 & 75,4 & 24,6 \\
\hline 2002. & 2752 & 2141 & 611 & 77,8 & 22,2 \\
\hline 2003. & 2666 & 2255 & 411 & 84,6 & 15,4 \\
\hline 2004. & 2309 & 1816 & 493 & 78,6 & 21,4 \\
\hline 2005. & 2246 & 1822 & 424 & 81,1 & 18,9 \\
\hline 2006. & 2380 & 1800 & 580 & 75,6 & 24,4 \\
\hline 2007. & 2312 & 1714 & 598 & 74,1 & 25,9 \\
\hline 2008. & 1996 & 1496 & 500 & 74,9 & 25,1 \\
\hline 2009. & 2284 & 1480 & 804 & 64,8 & 35,2 \\
\hline 2010. & 2338 & 1407 & 931 & 60,2 & 39,8 \\
\hline 2011. & 2276 & 1504 & 772 & 66,1 & 33,9 \\
\hline 2012. & 1958 & 1459 & 499 & 74,5 & 25,5 \\
\hline 2013. & 2700 & 1681 & 1019 & 62,3 & 37,7 \\
\hline 2014. & 3622 & 2028 & 1594 & 56,0 & 44,0 \\
\hline 2015. & 3877 & 1910 & 1967 & 49,3 & 50,7 \\
\hline 2016. & 4676 & 1913 & 2763 & 40,9 & 59,1 \\
\hline 2017. & 6821 & 1730 & 5091 & 25,4 & 74,6 \\
\hline Ukupno & 49771 & 30084 & 19597 & 60,4 & 39,6 \\
\hline
\end{tabular}

* Ne uključuje unutaržupanijske migracije.

Izvor: Publikacije prema statističkim područjima, Stanovništvo, Migracije stanovništva Republike Hrvatske, 7.1.2. Priopćenja o migraciji stanovništva, DZSRH, Zagreb (www.dzs.hr; pristupljeno 15. siječnja 2019.). 
Tablica 6. Opća stopa neto migracije stanovništva Vukovarsko-srijemske županije u razdoblju 2001. - 2017. godine

\begin{tabular}{|c|c|c|c|}
\hline Godina & $\begin{array}{l}\text { Saldo ukupne } \\
\text { migracije }\end{array}$ & $\begin{array}{l}\text { Procijenjeni broj stanovnika } \\
\text { sredinom godine }\end{array}$ & $\begin{array}{l}\text { Opća stopa } \\
\text { neto migracije }\end{array}$ \\
\hline 2001. & -281 & 190259 & $-1,5$ \\
\hline 2002. & -849 & 189603 & $-4,5$ \\
\hline 2003. & -954 & 188365 & $-5,1$ \\
\hline 2004 & -789 & 187040 & $-4,2$ \\
\hline 2005. & -718 & 186004 & $-3,9$ \\
\hline 2006. & -703 & 185113 & $-3,8$ \\
\hline 2007. & -191 & 184333 & $-1,0$ \\
\hline 2008. & -247 & 183866 & $-1,3$ \\
\hline 2009. & -1010 & 183057 & $-5,5$ \\
\hline 2010. & -1392 & 181148 & $-7,7$ \\
\hline 2011. & -1239 & 178959 & $-6,9$ \\
\hline 2012. & -871 & 177583 & $-4,9$ \\
\hline 2013. & -1624 & 175932 & $-9,2$ \\
\hline 2014 & -2579 & 173441 & $-14,9$ \\
\hline 2015. & -2712 & 169224 & $-16,0$ \\
\hline 2016. & -3526 & 165799 & $-21,3$ \\
\hline 2017. & -5665 & 159213 & -35.6 \\
\hline
\end{tabular}

* Ne uključuje unutaržupanijske migracije.

Izvor: Publikacije prema statističkim područjima, Stanovništvo, Migracije stanovništva

Republike Hrvatske, 7.1.2. Priopćenja o migraciji stanovništva, DZSRH, Zagreb

(www.dzs.hr; pristupljeno 15. siječnja 2019.); Publikacije prema statističkim područjima, Stanovništvo, 7.1.3. Procjene stanovništva Republike Hrvatske,

DZSRH, Zagreb (www.dzs.hr; pristupljeno 25. veljače 2019.). 


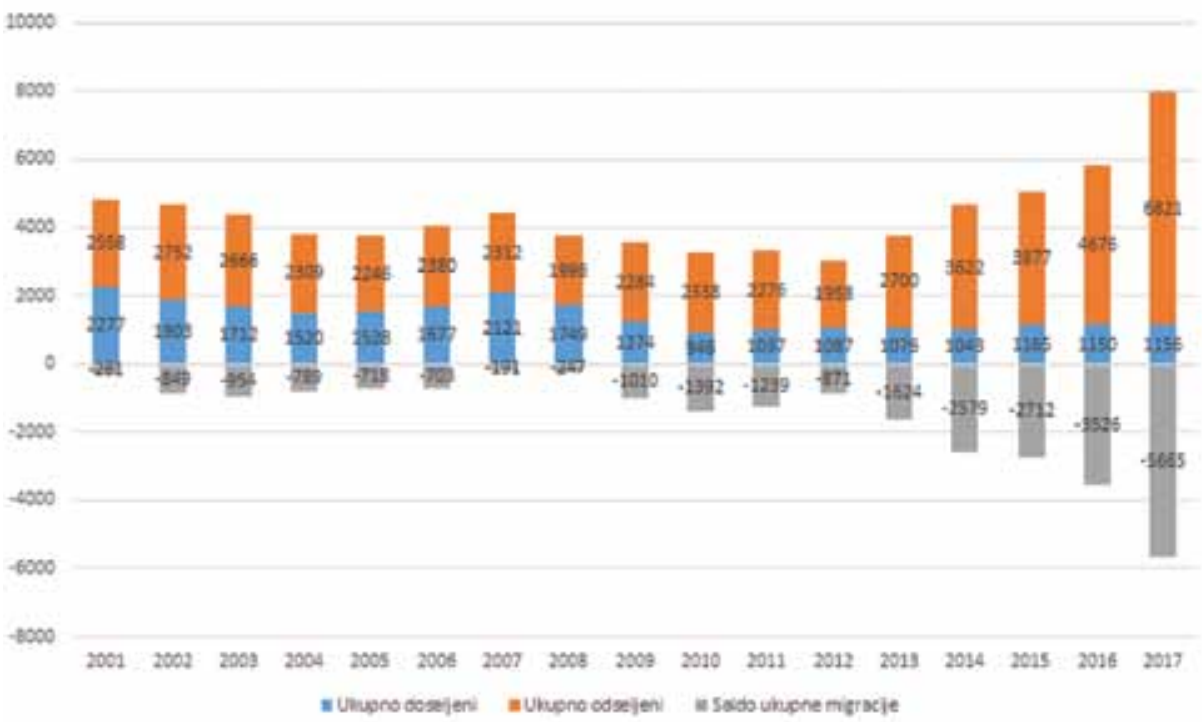

Grafikon 2. Broj doseljenih, broj odseljenih i saldo ukupne migracije Vukovarsko-srijemske županije 2001. - 2017. godine

Tablica 7. Opća stopa neto migracije stanovništva Vukovarsko-srijemske županije po gradovima/općinama za 2011. i 2017. godinu

\begin{tabular}{|l|c|c|}
\hline \multicolumn{1}{|c|}{ Grad/općina } & 2011. & 2017. \\
\hline Andrijaševci & $-0,4$ & $-17,9$ \\
\hline Babina Greda & $-11,3$ & $-69,3$ \\
\hline Bogdanovci & 1,0 & $-60,3$ \\
\hline Borovo & 2,6 & $-48,3$ \\
\hline Bošnjaci & $-16,1$ & $-70,2$ \\
\hline Cerna & $-10,1$ & $-50,8$ \\
\hline Drenovci & $-5,3$ & $-56,6$ \\
\hline Gradište & $-6,2$ & $-54,7$ \\
\hline Gunja & $-10,0$ & $-80,2$ \\
\hline Ilok & $-14,2$ & $-63,6$ \\
\hline Ivankovo & $-8,5$ & $-31,8$ \\
\hline Jarmina & $-4,5$ & $-17,2$ \\
\hline Lovas & $-21,1$ & $-54,1$ \\
\hline Markušica & $-4,3$ & $-26,2$ \\
\hline
\end{tabular}


Rad Hrvat. akad. znan. i umjet. Razred za druš. znan. 54=539(2019) : 163-203

\begin{tabular}{|l|c|c|}
\hline Negoslavci & 6,2 & $-29,0$ \\
\hline Nijemci & $-8,8$ & $-38,3$ \\
\hline Nuštar & $-10,4$ & 4,6 \\
\hline Otok & $-5,7$ & $-29,9$ \\
\hline Privlaka & $-11,3$ & $-26,2$ \\
\hline Stari Jankovci & $-21,1$ & $-28,9$ \\
\hline Stari Mikanovci & $-8,2$ & $-24,9$ \\
\hline Štitar & $-30,7$ & $-92,1$ \\
\hline Tompojevci & $-22,2$ & $-72,8$ \\
\hline Tordinci & $-21,0$ & $-23,4$ \\
\hline Tovarnik & $-10,5$ & $-79,7$ \\
\hline Trpinja & $-2,7$ & $-31,9$ \\
\hline Vinkovci & $-0,8$ & $-15,8$ \\
\hline Vođinci & $-2,5$ & $-24,8$ \\
\hline Vrbanja & $-4,6$ & $-59,2$ \\
\hline Vukovar & $-3,9$ & $-40,2$ \\
\hline Županja & $-15,2$ & $-53,1$ \\
\hline
\end{tabular}

Izvor: Kao tablica 6.

\subsection{Procjena demografske bilance 2011. - 2017. godine}

U tablicama 8 i 9 prezentirani su službeni podatci hrvatske vitalne i migracijske statistike za razdoblje 2011. - 2017. godine te izračunata demografska bilanca Vukovarsko-srijemske županije ukupno i po jedinicama lokalne samouprave za isto razdoblje. Kada je u pitanju Vukovarsko-srijemska županija, u cijelosti izneseni podatci, nema nikakve sumnje, upozoravaju na nastavak ukupne depopulacije. $\mathrm{U}$ analiziranih sedam godina gubitak stanovništva prirodnim putem dosegnuo je nova 5.304 stanovnika (10.890 rođenih i 16.194 umrla), dok je mehaničkim putem ili brojnijim odseljavanjem od doseljavanja izgubljeno još (najmanje) 18.216 stanovnika. To znači da je demografska bilanca ili zbroj prirodnoga pada i negativnoga salda ukupne migracije iznosio -23.520 stanovnika, što je $-13,1 \%$ u odnosu na broj stanovnika popisanih 2011. godine. U strukturi demografske bilance, „višak" umrlih nad živorođenima u prosjeku je za cijelo razdoblje sudjelovao s $25,8 \%$, a "višak" odseljenih nad doseljenim stanovništvom $74,2 \%$, iz čega proizlazi da je ukupno kretanje stanovništva Vukovarsko-srijemske županije nakon popisa 2011. godine pod dominantnim utjecajem emigra- 
cijske komponente (determinira približno tri četvrtine negativne demografske bilance), dok je bioreprodukcija signifikantno manje važnosti (determinira približno četvrtinu negativne demografske bilance). Od 2012. godine negativna demografska bilanca u stalnoj je progresiji - od -1.424 do -6.725 stanovnika, što indicira učetverostručenje njezine negativne vrijednosti u samo sedam godina, što je determinirano jačanjem negativnoga salda ukupne migracije, a on je, pak, ponajviše pod utjecajem rasta broja iseljenih iz Županije (ponajviše u druge hrvatske županije, ali sve više i u inozemstvo).

Spustimo li analizu veličine i strukture demografske bilance na razinu jedinica lokalne samouprave Vukovarsko-srijemske županije, razvidno je da je negativna demografska bilanca u razdoblju 2011. - 2017. godine prevladavajući demografski odnos između prirodnoga i mehaničkoga kretanja stanovništva u svim gradovima i općinama Županije. U apsolutnomu se smislu raspon negativne demografske bilance kretao od -139 u Općini Vođinci do -4.711 stanovnika u Gradu Vukovaru. U odnosu na popisom utvrđeni broj stanovnika iz 2011. godine raspon negativne demografske bilance kretao se od relativno niskih $-2,8 \% \mathrm{u}$ Gradu Vinkovci do čak -26,5\% u Općini Tompojevci.

Potrebno je ukazati i na činjenicu da, premda su sve administrativne jedinice Vukovarsko-srijemske županije u razdoblju 2011. - 2017. godine ostvarile negativnu demografsku bilancu, a to znači pad broja stanovnika, u strukturi toga smanjenja postoje manje razlike. Naime, općine Andrijaševci i Vođinci u promatranomu su razdoblju imale pozitivnu prirodnu promjenu, što znači da je u njima broj živorođene djece bio veći od broja umrlih osoba. Doduše, evidentirani prirodni prirast nije zamjetnije brojčane vrijednosti: samo 4 stanovnika u Općini Andrijaševci, odnosno 27 stanovnika u Općini Vođinci. S obzirom na to da su obje općine $u$ isto vrijeme imale veći broj odseljenih od doseljenih stanovnika (Andrijaševci za 170, a Vođinci za 166 osoba) u njima je iseljavanjem „dekompenziran“ prirodni porast te na taj način determinirana negativna demografska bilanca. U svim je ostalim gradovima i općinama Vukovarsko-srijemske županije negativna demografska bilanca determinirana migracijskom komponentom, $\mathrm{tj}$. negativnim saldom ukupne migracije, čiji se raspon u strukturi negativne demografske bilance kretao od najmanjih 54,1\% u Općini Markušica do čak 97,6\% u Općini Cerna. ${ }^{48}$ Drugim riječima, u Županiji i njezinim administrativnim jedinicama dominira emigracijsko obilježje demografske bilance.

48 Od ukupno 29 jedinica lokalne samouprave u Vukovarsko-srijemskoj županiji u kojima je negativna demografska bilanca determinirana i prirodnim i mehaničkim smanjenjem stanovništva, relativan udio migracijske komponente između 50\% i 60\% imale su 2 jedinice, između $60 \%$ i $70 \%$ imale su 4 jedinice, između $70 \%$ i $80 \%$ imalo je 15 jedinica, između $80 \%$ i $90 \%$ imale su 3 jedinice te između $90 \%$ i 100\% imalo je 5 administrativnih jedinica županije. 
Rad Hrvat. akad. znan. i umjet. Razred za druš. znan. 54=539(2019) : 163-203

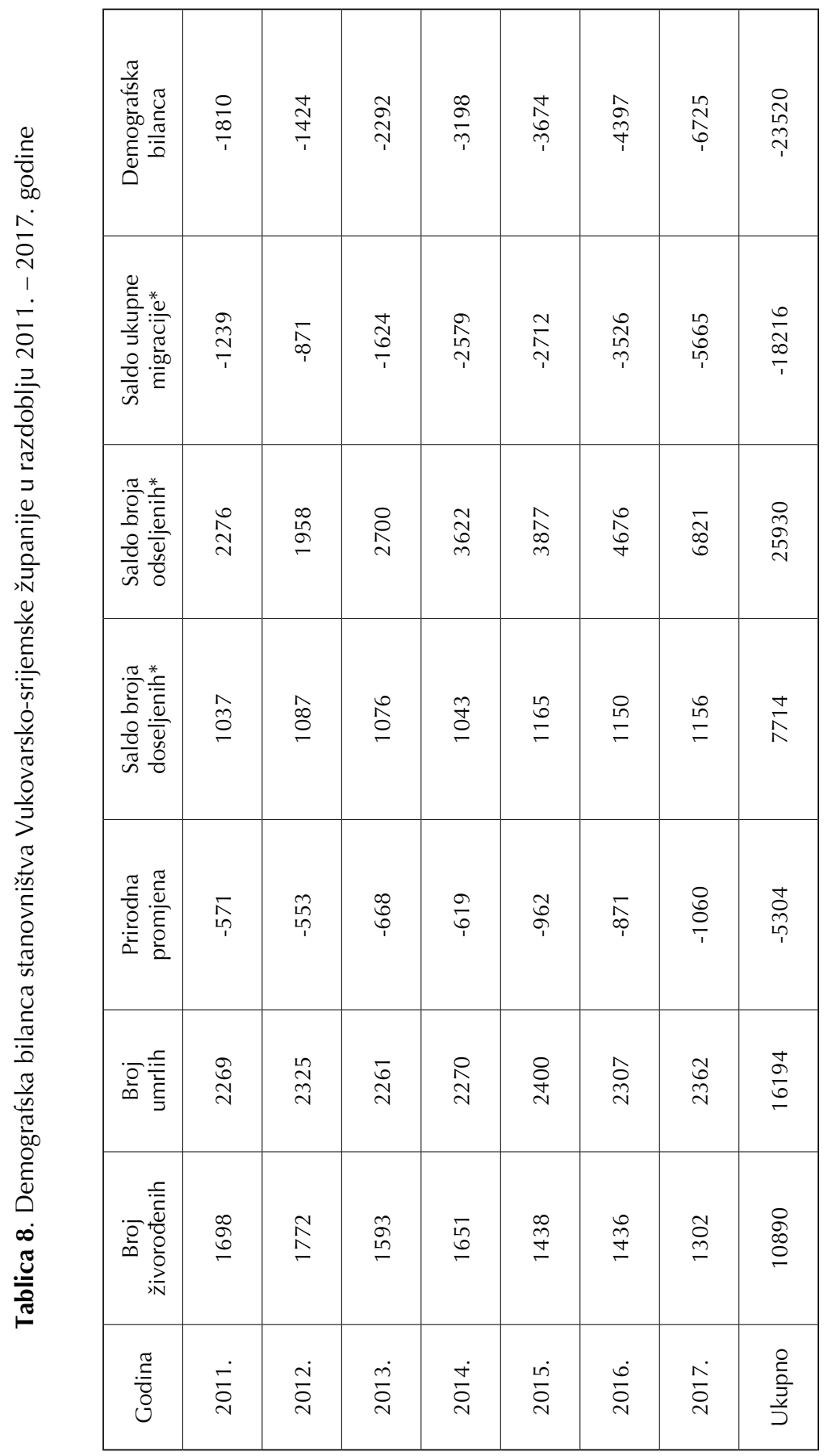

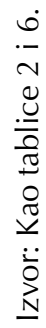

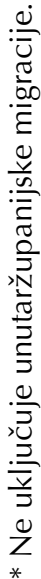


Rad Hrvat. akad. znan. i umjet. Razred za druš. znan. 54=539(2019) : 163-203

Dražen Živić: Migracijska komponenta ukupnoga kretanja stanovništva Vukovarsko-srijemske županije 2001. - 2017.

\begin{tabular}{|c|c|c|c|c|c|c|c|c|c|c|c|c|c|c|c|}
\hline 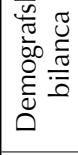 & $\begin{array}{l}0 \\
\stackrel{1}{1}\end{array}$ & $\begin{array}{l}20 \\
0 \\
0\end{array}$ & $\frac{N}{n}$ & 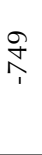 & 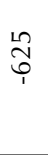 & $\stackrel{\text { Ln }}{\stackrel{5}{L}}$ & तิ & $\underset{f}{\bar{f}}$ & $\stackrel{m}{\uparrow}$ & $\begin{array}{l}\text { ̊ิ } \\
\stackrel{T}{T}\end{array}$ & $\begin{array}{l}\infty \\
\stackrel{\infty}{0} \\
\infty \\
\infty\end{array}$ & $\frac{\sigma}{7}$ & 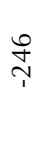 & $\underset{f}{f}$ & $\underset{\sim}{\stackrel{\Xi}{\sim}}$ \\
\hline 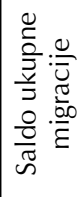 & $\frac{R}{r}$ & 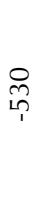 & 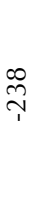 & $\begin{array}{l}\text { कo } \\
\text { ధి }\end{array}$ & సิ & त̂ & $\frac{m}{\varphi}$ & $\stackrel{\bar{n}}{m}$ & ิิ & 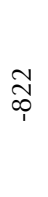 & $\underset{1}{\bar{T}}$ & 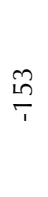 & $\frac{\infty}{\stackrel{\infty}{T}}$ & $\underset{\sim}{\stackrel{\sim}{\sim}}$ & $\stackrel{\sigma}{\stackrel{m}{r}}$ \\
\hline 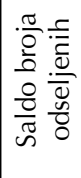 & Lे & $\stackrel{\oplus}{\wedge}$ & ช̃ & $\begin{array}{l}\text { D̃ } \\
\underset{\sim}{\sim}\end{array}$ & 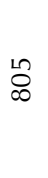 & $\hat{\mathscr{D}}$ & $\stackrel{ }{\underline{z}}$ & క్రి & $\frac{\infty}{\sigma}$ & $\stackrel{\stackrel{m}{m}}{m}$ & $\stackrel{\stackrel{\Perp}{N}}{\underset{\sim}{\simeq}}$ & $\begin{array}{l}\text { +े } \\
\text { r. }\end{array}$ & ๙ั & J & ڤे \\
\hline 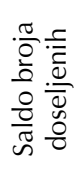 & 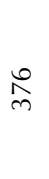 & 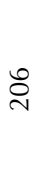 & $\stackrel{\leftarrow}{\stackrel{\leftarrow}{\sim}}$ & 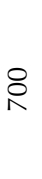 & 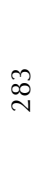 & $\bar{m}$ & के & $\stackrel{\circ}{\sim}$ & $\bar{m}$ & $\frac{m}{n}$ & $\stackrel{\varpi}{\rightarrow}$ & $\stackrel{n}{\sigma}$ & 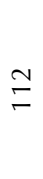 & $\stackrel{\Omega}{\circ}$ & $\stackrel{\infty}{\stackrel{\infty}{\oplus}}$ \\
\hline 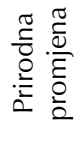 & $\nabla$ & $\stackrel{L}{\stackrel{2}{1}}$ & $\underset{i}{\stackrel{N}{*}}$ & $\underset{1}{\hat{\jmath}}$ & $\stackrel{m}{1}$ & $\frac{m}{1}$ & : & 8 & 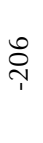 & $\begin{array}{l}0 \\
\infty \\
\dddot{r}\end{array}$ & $\stackrel{\hat{\imath}}{i}$ & $\stackrel{\circ}{+}$ & $\begin{array}{l}\infty \\
0 \\
1\end{array}$ & $\stackrel{\text { Ln }}{\stackrel{\Upsilon}{1}}$ & $\begin{array}{l}L 0 \\
\infty \\
1\end{array}$ \\
\hline 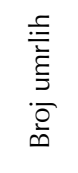 & $\stackrel{\text { }}{\sim}$ & 吊 & $\stackrel{\hat{\sigma}}{-}$ & $\frac{N}{7}$ & $\begin{array}{l}\infty \\
m \\
m\end{array}$ & $\stackrel{m}{n}$ & 占 & 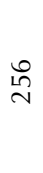 & مै & $\frac{\nabla}{\pi}$ & $\bar{\sigma}$ & $\stackrel{\text { }}{\sim}$ & $\tilde{\tilde{\sigma}}$ & $\begin{array}{l}\infty \\
\stackrel{\infty}{0}\end{array}$ & $\stackrel{\llcorner 0}{\sim}$ \\
\hline 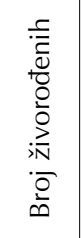 & ڤे & $\stackrel{\text { Ln }}{\curvearrowright}$ & $\stackrel{\widetilde{v}}{\sim}$ & $\stackrel{\llcorner}{\sim}$ & $\stackrel{\llcorner}{\sim}$ & O & $\stackrel{\stackrel{\circ}{N}}{\stackrel{2}{n}}$ & $\underset{0}{8}$ & $\infty$ & mे & 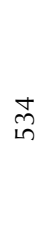 & in & $\stackrel{\circ}{\sigma}$ & ô & ஓ \\
\hline 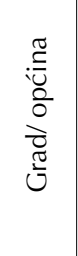 & 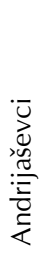 & 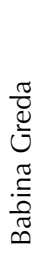 & 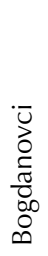 & $\begin{array}{l}0 \\
\text { o } \\
\frac{0}{0} \\
0\end{array}$ & 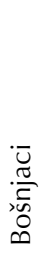 & 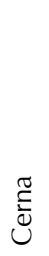 & 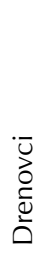 & 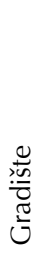 & $\frac{\cdot \frac{\sigma}{5}}{\mathfrak{J}}$ & $\stackrel{\text { 응 }}{=}$ & 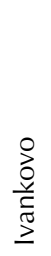 & 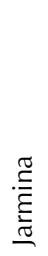 & 胥 & 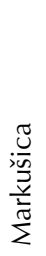 & 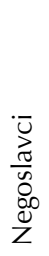 \\
\hline
\end{tabular}


Rad Hrvat. akad. znan. i umjet. Razred za druš. znan. 54=539(2019) : 163-203

Dražen Živić: Migracijska komponenta ukupnoga kretanja stanovništva Vukovarsko-srijemske županije 2001. - 2017.

\begin{tabular}{|c|c|c|c|c|c|c|c|c|c|c|c|c|c|c|c|}
\hline & 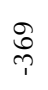 & \&̊ & 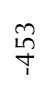 & $\begin{array}{l}0 \\
\infty \\
\infty \\
1\end{array}$ & 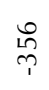 & $\stackrel{゚}{f}$ & $\frac{\operatorname{Ln}}{\gamma}$ & $\stackrel{+}{m}$ & 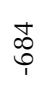 & $\begin{array}{l}\tilde{O}_{0} \\
\text { O) }\end{array}$ & $\begin{array}{l}0 \\
\infty \\
\text { ô }\end{array}$ & $\frac{\stackrel{m}{r}}{1}$ & ब్రి & $\underset{+}{\check{Y}}$ & $\begin{array}{l}\hat{\text { Oे }} \\
\text { }\end{array}$ \\
\hline $\begin{array}{l}\text { to } \\
\text { o } \\
\end{array}$ & ๙ิ & $\underset{⿱}{\stackrel{f}{+}}$ & 市 & $\frac{\sigma}{6}$ & $\hat{ָ}$ & $\stackrel{\odot}{\stackrel{Y}{\sim}}$ & 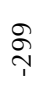 & $\underset{\sim}{\tilde{T}}$ & 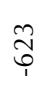 & $\frac{N}{i_{1}}$ & 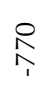 & \begin{tabular}{l}
0 \\
\hdashline \\
1
\end{tabular} & $\frac{n}{\sum_{1}}$ & $\underset{m}{\stackrel{m}{f}}$ & $\underset{\infty}{\infty}$ \\
\hline ฮิ & $\stackrel{8}{\circ}$ & $\underset{+}{\stackrel{0}{\mp}}$ & $\bar{L}_{\mathfrak{L}}$ & $\stackrel{8}{\varnothing}$ & $\hat{\vartheta}$ & $\begin{array}{l}\infty \\
\infty \\
\infty n\end{array}$ & $\stackrel{\text { f }}{f}$ & ஓ্ & $\begin{array}{l}\stackrel{R}{\infty} \\
\infty\end{array}$ & 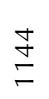 & $\begin{array}{l}\infty \\
\stackrel{8}{\circ} \\
\text { ட }\end{array}$ & $\stackrel{\circ}{\circ}$ & $\begin{array}{l}\stackrel{\ln }{\infty} \\
\stackrel{\infty}{N}\end{array}$ & $\underset{N}{\stackrel{N}{N}}$ & $\begin{array}{l}\text { ڤे } \\
\stackrel{\sim}{\sim}\end{array}$ \\
\hline$\frac{\infty}{m}$ & $\stackrel{\infty}{\circ}$ & ळे & $\stackrel{\llcorner}{\stackrel{0}{N}}$ & $\begin{array}{l}\hat{\infty} \\
\text { m }\end{array}$ & $\stackrel{\circ}{\sim}$ & $\underset{\sigma}{\sigma}$ & $\stackrel{\infty}{+}$ & $\stackrel{\stackrel{\sim}{\sim}}{ }$ & $\stackrel{\stackrel{े}{v}}{ }$ & స్ & $\begin{array}{l}\stackrel{\infty}{\stackrel{7}{\sim}} \\
\text { }\end{array}$ & q & $\stackrel{N}{N}$ & $\begin{array}{l}m \\
\stackrel{\infty}{\infty}\end{array}$ & হ్ \\
\hline $\begin{array}{l}\stackrel{\infty}{\infty} \\
\text { Tे }\end{array}$ & $\stackrel{\wedge}{\wedge}$ & 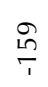 & $\stackrel{\hat{0}}{7}$ & $\begin{array}{l}\hat{\infty} \\
\overline{1}\end{array}$ & $\underset{\sim}{\stackrel{1}{1}}$ & $\bar{\tau}$ & $\frac{0}{7}$ & $\stackrel{\Re}{\Re}$ & $\bar{\varphi}_{1}$ & 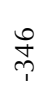 & $\frac{0}{i}$ & $\hat{\imath}$ & $\underset{+\infty}{+\infty}$ & $\begin{array}{l}\infty \\
\stackrel{\infty}{0} \\
\underset{N}{N}\end{array}$ & $\underset{\sim}{\stackrel{+}{\sim}}$ \\
\hline 눈 & ळे & 岕 & $\underset{\sim}{\stackrel{D}{2}}$ & $\stackrel{8}{+}$ & $\bar{n}$ & $\underset{\sim}{0}$ & $\stackrel{\llcorner}{\infty}$ & $\hat{\text { }}$ & $\stackrel{\infty}{\stackrel{\infty}{\sim}}$ & $\frac{10}{6}$ & 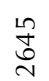 & $\stackrel{\stackrel{P}{+}}{\square}$ & $\frac{\infty}{\sigma}$ & $\underset{\sim}{\stackrel{+}{\sim}}$ & $\begin{array}{l}0 \\
\infty \\
\infty\end{array}$ \\
\hline 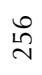 & ర్ల & $\stackrel{\sim}{\dddot{\gamma}}$ & $\stackrel{\mathscr{L}}{\sim}$ & 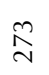 & $\underset{\sim}{\sim}$ & $\stackrel{\stackrel{\sim}{+}}{\leftarrow}$ & oి & $\stackrel{+}{\sim}$ & $\stackrel{\widehat{\sigma}}{\sigma}$ & $\underset{\sim}{\stackrel{\circ}{2}}$ & $\begin{array}{l}\stackrel{\sim}{ \pm} \\
\stackrel{\sim}{\sim}\end{array}$ & $\underline{\sigma}$ & $\stackrel{+}{\sim}$ & $\begin{array}{l}\stackrel{0}{\sim} \\
\leftarrow\end{array}$ & $\begin{array}{c}0 \\
0 \\
0\end{array}$ \\
\hline 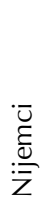 & 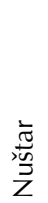 & $\begin{array}{l}\frac{1}{0} \\
0\end{array}$ & $\frac{\frac{\pi}{\pi}}{\stackrel{\pi}{\frac{\pi}{2}}}$ & 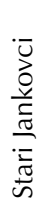 & 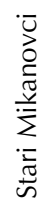 & 离 & 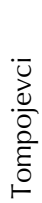 & $\begin{array}{l}\bar{U} \\
. \bar{E} \\
\overline{0} \\
\circ\end{array}$ & 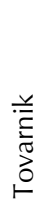 & 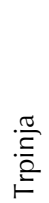 & $\begin{array}{l}\bar{y} \\
\bar{o} \\
\bar{v} \\
\bar{J}\end{array}$ & 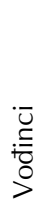 & $\begin{array}{l}\frac{\sigma}{\sigma} \\
\frac{0}{\sigma} \\
\frac{0}{2}\end{array}$ & 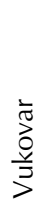 & 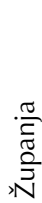 \\
\hline
\end{tabular}




\section{ZAKLJUČAK}

Unatoč objektivnim metodološkim ograničenjima, osobito kada je u pitanju pouzdanost i cjelovitost hrvatske migracijske statistike, ipak se može na aproksimativnoj razini ocijeniti utjecaj migracijske komponente na ukupno kretanje stanovništva i demografsku bilancu Vukovarsko-srijemske županije kroz analizirano razdoblje 2001. - 2017. godine. Migracije, kao uostalom i bioreprodukcija, negativne su i izrazito destabilizacijske odrednice ukupne demografske dinamike Vukovarsko-srijemske županije koja nepovoljan (kratkoročan) utjecaj ima na promjenu broja stanovnika (nastavak ukupne depopulacije), na prerazmještaj stanovništva unutar Županije, kao i na smanjenje opće relativne gustoće naseljenosti, dok se dugoročni demografski učinci negativnoga migracijskoga salda, zbog selektivnosti iseljeničko-doseljeničkih struja, očituju u predvidivoj daljnjoj redukciji nataliteta i produbljenju disbalansa u odnosu među velikim dobnim skupinama funkcionalno bitnim za formiranje fertilnih, radnosposobnih i radnoaktivnih kohorti vukovarsko-srijemske populacije. Naime, brojčano osiromašene generacije zbog odgođenog učinka iseljavanja, kako unutarhrvatskoga tako i prema inozemstvu, imat će osjetno manji reproduktivni učinak, a to će, uz ostale nepovoljne činitelje, rezultirati velikim problemima po pitanju popunjavanja sve većih demografskih praznina na tržištu rada u Županiji.

Proces demografskoga starenja u Vukovarsko-srijemskoj županiji u uzlaznom je trendu. Sve niži natalitet generira sužavanje dobnih kohorti mladoga stanovništva, a to će, predvidivo, s motrišta buduće migracije značiti postupno smanjenje potencijalnoga broja migranata (iseljenika). No dosadašnji i postojeći (ne)razvojni trendovi u društvenomu i gospodarskomu razvoju Vukovarsko-srijemske županije i cijele istočne Hrvatske još su uvijek jak push faktor emigracije, a nikakav ili vrlo skroman pull faktor imigracije. Iz toga proizlazi zaključak da će negativan saldo ukupne migracije i u sljedećem barem kratkoročnom razdoblju biti dominantna komponenta demografske bilance i ukupnoga kretanja stanovništva Vukovarsko-srijemske županije. 


\section{POPIS LITERATURE}

Akrap, Anđelko, 2014. Promjene broja i prostornog razmještaja stanovništva Hrvatske i županija 1961. - 2011., u: Migracije i razvoj Hrvatske. Podloga za hrvatsku migracijsku strategiju (Puljiz, Vlado, Tica, Josip, Vidović, Davorko, ur.), Zagreb: Hrvatska gospodarska komora, 25-71.

Akrap, Anđelko, Strmota, Marin, Ivanda, Krešimir, 2017. Iseljavanje iz Hrvatske od početka 21. stoljeća: uzroci i posljedice, u: Zbornik radova Hrvatska izvan Domovine II (Sopta, Marin, Lemić, Vlatka, Korade, Mijo, Rogić, Ivan, Perić Kaselj, Marina, ur.), Zagreb: Centar za istraživanje hrvatskog iseljeništva, 543-551.

Aračić, Pero (gl. ur.), 2018. Kamo ide istočna Hrvatska? Demografsko stanje, prognoze $i$ traženje izlaska iz krize Slavonije, Baranje i zapadnog Srijema, Zbornik radova sa znanstvenoga skupa, Zagreb - Đakovo: Hrvatska akademija znanosti i umjetnosti. Zavod za znanstveni i umjetnički rad u Đakovu.

Draženović, Ivana, Kunovac, Marina, Pripužić, Dominik, 2018. Dynamics and determinants of emigration: the case of Croatia and the experience of new EU member states, Public Sector Economics, 42, 4, 415-447.

Gelo, Jakov, Akrap, Anđelko, Čipin, Ivan, 2005. Temeljne značajke demografskog razvoja Hroatske (bilanca 20. stoljeća), Zagreb: Ministarstvo obitelji, branitelja i međugeneracijske solidarnosti.

Jurić, Tado, 2017. Suvremeno iseljavanje Hrvata u Njemačku: karakteristike i motivi, Migracijske i etničke teme, 33, 3, 337-371.

Karaman, Igor (ur.). 1994. Vukovar - vjekovni hrvatski grad na Dunavu, Koprivnica: Naklada dr. Feletar.

Klempić Bogadi, Sanja, Lajić, Ivan, 2014. Suvremena migracijska obilježja statističkih jedinica Republike Hrvatske, Migracijske i etničke teme, 30, 3, 437-477.

Lajić, Ivan, 2002. Hrvatske migracije početkom 21. stoljeća, Migracijske i etničke teme, 18, 2-3, 135-149.

Nejašmić, Ivo, 2005. Demogeografija - stanovništvo u prostornim odnosima i procesima, Zagreb: Školska knjiga.

Nejašmić, Ivo, 2008. Stanovništvo Hrvatske: demogeografske studije i analize, Zagreb: Hrvatsko geografsko društvo.

Nejašmić, Ivo, 2014. Iseljavanje iz Hrvatske od 1900. do 2001.: demografske posljedice stoljetnog procesa, Migracijske i etničke teme, 30, 3, 405-435.

Pejaković, Tomislav, 2016. Biološki sastav i starenje stanovništva Vukovarsko-srijemske županije 1961. - 2011. godine, Hrvatski geografski glasnik, 78, 1, 125-158.

Pokos, Nenad, 2017. Osnovna demografska obilježja suvremenog iseljavanja iz Hrvatske, Političke analize, 31, 16-23.

Rajković Iveta, Marijeta, Horvatin, Tea, 2017. Suvremeno iseljavanje iz Hrvatske u Irsku s posebnim osvrtom na mlade iz Slavonije, Migracijske i etničke teme, 33, 3, 247-274. 
Šola, Ivica, Bičvić, Marijana. 2018. Ekonomsko iseljavanje iz Slavonije u SR Njemačku. Neka identitetska, psihološka i etička pitanja, Bogoslovska smotra, 88, 1, 157-175.

Vurnek, Dragutin, Bengez, Andrea, Perkov, Matej, 2018. Sigurnosni aspekti migracija, Acta Economica Et Turistica, 4, 2, 121-214.

Wertheimer-Baletić, Alica, 1993.a. Jedno i pol stoljeće u brojčanom razvoju stanovništva Vukovara i vukovarskoga kraja, Društvena istraživanja, 2, 4-5, 455-477.

Wertheimer-Baletić, Alica, 1993.b Stanovništvo Vukovara i vukovarskog kraja, Zagreb: Nakladni zavod Globus.

Wertheimer-Baletić, Alica, 1997. Razvoj stanovništva Vukovara (1857. - 1991.), u: Zbornik radova o Vukovarsko-srijemskoj županiji (Klepac, Dušan i Čorkalo, Katica ur.), Vinkovci: Hrvatska akademija znanosti i umjetnosti. Centar za znanstveni rad Vinkovci, 41-62.

Wertheimer-Baletić, Alica, 1999. Stanovništvo i razvoj, Zagreb: MaTe. Gospodarska misao.

Wertheimer-Baletić, Alica, Akrap, Anđelko, 2008. Razvoj stanovništva Vukovarskosrijemske županije s posebnim osvrtom na ekonomsku strukturu od 1971. do 2001., Društvena istraživanja, 17, 1-2, 51-75.

Wertheimer-Baletić, Alica, 2017. Demografski procesi u Hrvatskoj i u zapadnoeuropskim zemljama - razlike, sličnosti i specifičnosti, Rad Hrvatske akademije znanosti i umjetnosti: Razred za društvene znanosti, 529, 1-28.

Wertheimer-Baletić, Alica, 2017.a. Demografska teorija, razvoj stanovništva Hrvatske i populacijska politika (Izbor radova), Samobor: Meridijani izdavačka kuća.

Živić, Dražen, 2006. Stanovništvo Vukovarsko-srijemske županije (odrednice i obilježja demografskih promjena od sredine 19. do početka 21. stoljeća), Zagreb - vukovar: Institut društvenih znanosti Ivo Pilar, Ogranak Matice hrvatske u Vukovaru.

Živić, Dražen, Turk, Ivo, 2011. Demografski gubitci Vukovarsko-srijemske županije u Hrvatskom domovinskom i obrambenom ratu, u: Žrtva znak vremena. Zbornik radova Petog hrvatskog žrtvoslovnog kongresa (Šeparović, Zvornimir, ur.), Zagreb: Hrvatsko žrtvoslovno društvo, 542-554.

Živić, Dražen, 2012. Stanovništvo Vukovarsko-srijemske županija - procesi, trendovi i perspektive, u: Vukovarsko-srijemska županija - prostor, ljudi, identitet (Živić, Dražen, ur.), Vukovar - Zagreb: Vukovarsko-srijemska županija i Institut društvenih znanosti Ivo Pilar, 27-54.

Živić, Dražen, 2016. Suvremena migracija kao odrednica depopulacije istočne Hrvatske, u: Zbornik radova Sociokulturno nasljeđe i gospodarski razvoj (Šundalić, Antun, Zmaić, Krunoslav, Sudarić, Tihana, Pavić, Željko, ur.), Osijek: Sveučilište J. J. Strossmayera u Osijeku, Poljoprivredni fakultet, Odjel za kulturologiju, Ekonomski fakultet, 52-75.

Živić, Dražen, Turk, Ivo, Šimunić, Nikola, 2017. Demografske promjene u Vukovarskosrijemskoj županiji (2001. - 2014.) u zrcalu nacionalne sigurnosti, u: Domovinska (i europska) sigurnost. Kriza sigurnosti i politike manipuliranja suverenitetom (Cvikić, Sandra, Žebec Šilj, Ivana, Bendra, Ivana, ur.), Zagreb - Vukovar: Institut društvenih znanosti Ivo Pilar, 39-72. 


\section{Summary}

\section{The Migration Component of the Total Movement of the Population in the Vukovar-Srijem County 2001-2017}

The subject of the demographic analysis conducted in this paper are the components/determinants of the total movement of the population and the demographic balance of the Vukovar-Srijem County in the period between the census of 2001 and the year 2017, with a special emphasis on the mechanical (migration) component of the total movement of the population. The research aimed at defining the size and structure of demographic balance, and - using the comparative vital-statistical method - assessing the rough migration balance and evaluating the importance of modern migrations - in the subject period and in the context of the movement and development of the population in the Vukovar-Srijem County (in total, and at the level of local self-administration units - towns and municipalities), with the aim of recognising the dominant modern dynamic features of its demographic development. The demographic analysis has been conducted on the basis of the demographicstatistical documentation relating to the available (published) census-related, vital and migration statistics. The comparative analysis has shown that the Vukovar-Srijem County suffers from total depopulation as a type of inter-census change; natural decrease as a consequence of the ever increasing number of deaths at birth; and the negative balance of the total migration as a result of prevailing emigration over immigration of the population. The demographic balance of the Vukovar-Srijem County was hence negative even in the period following the so far last census conducted in 2011. The prevailing determinant of the negative migration balance is strong emigration, not only to other Croatian counties, but also - and increasingly - to foreign countries. The ever increasing loss of population by natural and - in particular - mechanical means (emigration) presents an extremely unfavourable long-term determinant of the demographic, social and economic revitalisation of the Vukovar-Srijem County, which was gravely destroyed in the aggression war in the 1990s.

Keywords: Vukovar-Srijem County; total movement; natural movement; migrations; demographic balance; depopulation; demographic aging. 